\title{
THE COMBINED EFFECT BETWEEN IRRIGATION AND K-FERTILIZER FORMS ON SQUASH PRODUCTIVITY IN THE NORTH NILE DELTA REGION
}

\author{
(Received:24.5.2015)
}

\author{
By \\ D. Kh.Farrag, R. Kh. Darwesh* and E. A. Moursi* \\ Horticulture Research Institute, and * Soils, Water and Environment Research Institute, \\ Agriculture Research Center, Giza, Egypt.
}

\begin{abstract}
The current experiment was carried out in a clay soil at Sakha Agricultural Research Station, Kafr El-Sheikh Governorate, Egypt during the two seasons of 2013 and 2014 to study the effect of irrigation and potassium fertilizer forms on squash productivity and some water relations. Four irrigation treatments: traditional irrigation $\left(\mathrm{I}_{0}\right)$, irrigation according to class A pan evaporation $\left(\mathrm{I}_{1}\right)$, irrigation according to Hargreaves equation 1981, $\left(\mathrm{I}_{2}\right)$ and irrigation according to Ibrahim equation $1980,\left(\mathrm{I}_{3}\right)$ were tested. Five K-fertilizer forms; $100 \%$ potassium mineral fertilizer $\left(\mathrm{K}_{1}\right), 75 \%$ potassium mineral fertilizer and $25 \%$ rock feldspar $\left(\mathrm{K}_{2}\right), 50 \%$ potassium mineral fertilizer and $50 \%$ rock feldspar $\left(\mathrm{K}_{3}\right), 25 \%$ potassium mineral fertilizer and $75 \%$ rock feldspar $\left(\mathrm{K}_{4}\right)$ and $100 \%$ rock feldspar $\left(\mathrm{K}_{5}\right)$ were tested. The important findings could be summarized as follows:

1- The highest overall mean values of water applied (IW) and water consumptive use (CU) were recorded under the control treatment (irrigation without any stress during the growing season, treatment, $\left.\mathrm{I}_{0}\right)$ where the values were $48.89 \mathrm{~cm}\left(2053.5 \mathrm{~m}^{3} \mathrm{fed}^{-1}\right)$ and $42.44 \mathrm{~cm}$ for WI and CU, respectively, but consumptive use efficiency (Ecu, \%) recorded under $\mathrm{I}_{1}$ had a mean value 93.44\%. Irrigation with $\mathrm{I}_{1}, \mathrm{I}_{2}$ and $\mathrm{I}_{3}$ saved irrigation water by $12.05,20.59$ and $16.75 \%$ for IW. The linear regression equations between irrigation water applied and K-fertilizers forms proved that the relation between IW and CU was more reliable in the two seasons.

2- Productivity of irrigation water (PIW $\mathrm{kgm}^{-3}$ ) on fresh yield basis increased with more frequent irrigation application, while water productivity $\left(\mathrm{WP} \mathrm{kgm}^{-3}\right)$ was the highest under $\mathrm{I}_{2}$ with overall mean value of $12.35 \mathrm{kgm}^{-3}$.

3- Vegetative parameters (shoots and dry weight, plant height, number of leaves per plant and leaf area) were significant for both irrigation and K-forms, as the interaction between I and K had significant effect, except plant height and the number leaves per plant in the second season which were non-significant. Increasing irrigation applied increased all vegetative growth parameters.

4- Results also showed that irrigation water applied and K-fertilization forms had significant effects on yield and its quality. The best combination of treatments was $\mathrm{I}_{0} * \mathrm{~K}_{3}$ with 149.5 and $160.0 \mathrm{~g}$, for weight of fruit, 5.90 and $6.28 \mathrm{ton} \mathrm{fed}^{-1}$ for total yield, 22.65 and $23.55 \mathrm{ton} \mathrm{fed}^{-1}$, 5.58 and 5.90 ton $\mathrm{fed}^{-1}$ for early yield, 15.20 and $15.60 \mathrm{mg} 100 \mathrm{~g}^{-1}$ fresh weight for vitamin C and 4.92 and $4.67 \%$ for TSS in the first and second seasons, respectively.

5- The values of N P K and chlorophyll content in the leaves were significantly affected by I and $\mathrm{K}$. Also, the interaction between I*K showed highly significant effect on the above mentioned studied parameters.
\end{abstract}

Key words: Squash, water applied, K-fertilizer forms, consumptive use, water productivity.

\section{INTRODUCTION}

Agriculture is the largest user of freshwater, accounting for about $75 \%$ of current withdrawals (Wallace, 2000). Food production from irrigated systems represents $\sim 40 \%$ of the global total and uses only about $18 \%$ of the land area allocated to food production (Fereres and Connor, 2004).

In Egypt, water share from the main water source. The River Nile is limited by 55.5 x $10^{9} \mathrm{~m}^{3} /$ year which is not enough to meet the increasing demand of all sectors . About $85 \%$ of The Egyptian water consumption is used in the 
agricultural sector. The necessity to rationalize the use of irrigation water becomes a must. Maximizing the benefit of irrigation water by crops is the main issue in the agricultural sector to increase crop production in order to narrow the food gap.

It is necessary to get maximum crop yield in agriculture by using available water in order to get maximum profit per unit area because existing agriculture land and irrigation water are rapidly diminishing due to rapid industrialization and urban development (Eretk et al., 2004). Deficit irrigation will play an important role in farm-level water management strategies, with consequent increases in the output generated per unit of water used in agriculture. Deficit irrigation is successful in increasing water productivity for different crops without causing severe yield reduction. Deficit irrigation is a strategy that allows a crop to sustain some degree of water deficit in order to reduce costs and potentially increase income. It can lead to increase in the net income where water costs are high or where water supplies are limited (Kirda et al., 2002).

To manage plant water stress, it is necessary to carefully schedule irrigation which consists of determining the amount and timing of irrigation applications (Martin et al., 1990). There are two main methods to schedule irrigation: (1) by replacing crop evapotranspiration (ETc) fractions according to a soil water balance by using irrigation equations were calculated and applied to the soil, or (2) by triggering irrigation according to water content status of the soil and allowable depletion levels (Hanson et al., 2000). Irrigation schedules have important roles in irrigation water use efficiency (IWUE) in vegetable crop production (Zotarelli et al., 2008).

In irrigated cropping systems, farmers tend to avoid risk by applying excessive amount of irrigation water in relation to crop water requirements to ensure maximum yield (Fereres and Gonzalez-Dugo, 2009).

Seasonal consumptive use values are useful in scheduling irrigation, and are obtained by summing the daily ET values in a cropped field throughout an entire season. Peak period $\mathrm{Cu}$ is particularly useful for irrigation system design, as ET, $\mathrm{Kc}$ and $\mathrm{Cu}$ are also affected by crop type, plant growth stage and weather conditions (Michael, 2006)

The average water yield is about 58 billion $\mathrm{m}^{3}$ /year, or less than $500 \mathrm{~m}^{3}$ per capita, thus indicating extreme water scarcity. Water scarcity is both anthropogenic and due to climate variation as analysed by Wang et al. (2006).

Water productivity (WP) offers a quantifiable benchmark to assess crop production in relation to available water resources (Bouman et al., 2005). WP can be defined in several ways depending on the temporal and spatial scales of concern and study objectives.

Potassium has a significant role in all processes needed to plant growth and reproduction such as photosynthesis, translocation of photosynthates, protein synthesis, and control of ionic balance, stress tolerance and water use (Marschner, 1995)

In Egypt, farmers use large amount of Kchemical fertilizers (as potassium sulphate) to maximize crop yield. These fertilizers are expensive and cause environmental pollution. Natural potassium fertilizer is a low cost resource for providing plants with $\mathrm{K}$ which could alternate the expensive applied Kchemical fertilizers. (Labib et al., 2012).

The mean source of $\mathrm{K}$ for plant growing under natural conditions comes from weathering of $\mathrm{K}$ minerals ( $\mathrm{k}$-feldspar, $\mathrm{k}$-mica and illite) (Hellal et al.,2009). K-feldspar may be available as a slow releasing fertilizer and cheaper source of K (Abou-el-soud, 2012 and Labib et al.,2012)

Summer squash is sensitive to, and may be damaged by, excessive soil water from seed sowing to emergence. Since summer squash rooting depth is relatively shallow, soil water has to be maintained above $65 \%$ of the available soil water capacity in order to avoid detrimental water deficit (Mario et al., 1997). Squash roots, most of which are in the top of $40-50 \mathrm{~cm}$ of soil, develop rapidly. Irrigation should be scheduled to avoid excessive moisture or water stress. Lack of adequate soil water at harvest can result in misshapen fruits, but too much soil water can aggravate root and stem rot diseases (Richard et al., 2002).

The ultimate target for the present investigation was to supply the right amounts of water needed for the plants, that is, plant water consumption through determining the most suitable irrigation and K-fertilizer programs for squash grown under field conditions.

\section{MATERIAL AND METHODS}

This study was carried out in a clay soil at the Horticultural Research field, Sakha Agricultural Research Station, Kafr El-Sheikh Governorate (Middle North Nile Delta) Egypt during the two 
seasons of 2013 and 2014 to study the effect of irrigation methods, potassium fertilizer forms and some water relations on squash productivity. The experimental design was a split plot involving two factors; main treatment (irrigation scheduling) and sub main treatments (Kfertilizers forms).

Data presented in Table (1) show the meteorological parameters during the studied period, recorded from Sakha Agrometeorological Station. The meteorological parameters, include; air temperature $\left(\mathrm{T} ., \mathrm{C}^{\circ}\right)$, relative humidity $(\mathrm{RH} ., \%)$, wind speed $\left(\mathrm{U}_{2}, \mathrm{~m}\right.$ $\sec ^{-1}$ day $^{-1}$ at $2 \mathrm{~m}$ height) and evaporation pan (Ep, mm day ${ }^{-1}$ ).

Soil particle size distribution and bulk density were determined as described by Klute (1986). Field capacity, permanent wilting point and available water characters were determined according to James (1988). Chemical characteristics of soil were determined as described by Jackson (1973) and all data are presented in Table (2).

Squash (Mabrouka, hybrid) seedlings, 18 days of age, were transplanted on one side of the ridge in hills spaced $0.40 \mathrm{~m}$ apart giving a plant density of about three plants $\mathrm{m}^{-2}$. Transplanting dates were on April 18, 2013 and April 22, 2014. The experimental plot area equals $64 \mathrm{~m}^{2}(1 / 65$ feddan) and contains 8 ridges.

\section{I. Main-treatments (irrigation scheduling) were as follows}

2.1.1.Traditional irrigation, control (direct method), $\mathbf{I}_{0}$

The irrigation flow rate per plot was controlled and measured till water reached the end of the plot.

\subsubsection{Class A pan evaporation method}

As:

$$
\mathrm{ET}_{\mathrm{o}}=\mathrm{K}_{\mathrm{p}} * \mathrm{E}_{\mathrm{p}}
$$

$\mathrm{ET}_{\mathrm{O}}=$ reference evapotranspiration, $\mathrm{mm}$,

$\mathrm{Kp}=$ pan coefficient, values of $\mathrm{Kp}$ affected with the surrounding area, where the pan is located and it was taken as an average value of 0.85 .

$\mathrm{Ep}=$ daily evaporation rate, $\mathrm{mm}$.

2.1.3. Irrigation according to Hargreaves et al.,equation (1985) , $\left(\mathrm{I}_{2}\right)$

$\mathrm{ET}_{0}=0.0023 \mathrm{Ra} \cdot \mathrm{TD}^{0.5}(\mathrm{Ta}+17.8)$ as :

$\mathrm{ETo}=$ reference evapotranspiration, $\mathrm{mm}$,

$\mathrm{Ra}=$ extraterrestrial radiation

$\mathrm{TD}=$ difference of temperature $\left(\mathrm{T}_{\max }-\mathrm{T}_{\min }\right)$

$\mathrm{Ta}=$ mean temperature

\subsubsection{Irrigation according to Ibrahim} equation (1981), $\left(\mathbf{I}_{3}\right)$ :

$$
\mathrm{ET}_{0}=0.1642+0.8 \mathrm{Ep} \quad \text { as: }
$$

$\mathrm{ETo}=$ reference evapotranspiration, $\mathrm{cm}$,

$\mathrm{Ep}=$ pan evaporation $(\mathrm{cm} /$ day $)$

Etc $=$ crop evapotranspiration $(\mathrm{cm} /$ day $)$

\section{-Computation of crop evapotranspiration} (ETc)

$$
\mathrm{ET}_{\mathrm{c}}=\mathrm{K}_{\mathrm{c}} * \mathrm{ET}_{\mathrm{o}}
$$

The dimensionless crop coefficient, $\mathrm{Kc}$ is the ratio between the water consumed by specific crop to $\mathrm{ET}_{\mathrm{o}}$. values of $\mathrm{K}_{\mathrm{c}}$ were quoted from Allen et al. (1998) FAO No. 56, 1998.

\subsection{Sub treatments (K-fertilizer forms)}

2.2.1.100\% Potassium mineral fertilizer $\left(\mathrm{K}_{1}\right)$,

2.2.2.75\% Potassium mineral fertilizer and $25 \%$ Rock feldspar $\left(\mathrm{K}_{2}\right)$,

2.2.3.50\% Potassium mineral fertilizer and $50 \%$ Rock feldspar $\left(\mathrm{K}_{3}\right)$,

2.2.4.25\% Potassium mineral fertilizer and $75 \%$ Rock feldspar $\left(\mathrm{K}_{4}\right)$ and

\subsubsection{0\% Rock feldspar $\left(\mathrm{K}_{5}\right)$}

With K-feldspar $\left(10-12 \% \mathrm{~K}\right.$ in phase $\left.\mathrm{K}_{2} \mathrm{O}\right)$ soil application technique, rock feldspar was distributed and incorporated into the soil surface before transplanting with $400 \mathrm{~kg}$ rock feldspar /fed rate. Whereas with the mineral technique, $\mathrm{K}$ was applied as $100 \mathrm{~kg}$ potassium sulphate, in two equal doses $(50 \mathrm{~kg} / \mathrm{fed}$. each), was distributed and incorporated into the soil surface before transplanting and the second dose added at 30 days after transplanting. The tested treatments were subjected to four replicates.

\subsection{Data collection}

\subsubsection{Irrigation water applied (I.W)}

Irrigation water was controlled and measured by flow rates from orifice discharging is the orifice meter and water was distributed and maintained by spills inserted beneath the bank of each irrigated furrows set. Applied irrigation water quantity was determined according to Michael (1978) as follows:

$$
\mathrm{Q}=\mathrm{CA} \sqrt{2 \mathrm{gh}}
$$

Where:

$\mathrm{Q}=$ Water discharge, $\mathrm{cm}^{3} \mathrm{sec}^{-1}$

$\mathrm{C}=$ coefficient of discharge ranged from 0.6 up to 0.8 or more

$\mathrm{A}=$ orifice cross - sectional area, $\mathrm{cm}^{2}$

$\mathrm{g}=$ acceleration due to of gravity, $981 \mathrm{~cm} \mathrm{sec}^{-2}$ and

$\mathrm{h}=$ pressure head causing water discharge, $\mathrm{cm}$ 
Table (1): Means of some meteorological data at Kafr El-Sheikh area during the two growing seasons of 2013 and 2014.

\begin{tabular}{|c|c|c|c|c|c|c|c|c|c|}
\hline \multirow[b]{2}{*}{ Months } & \multicolumn{3}{|c|}{$\mathbf{T}\left(\mathbf{c}^{\circ}\right)$} & \multicolumn{3}{|c|}{ RH(\%) } & \multirow{2}{*}{$\begin{array}{l}\mathbf{U}_{2} \mathbf{m} \\
\mathbf{S e c}^{-1}\end{array}$} & \multirow{2}{*}{$\begin{array}{c}\text { Pan } \\
\text { Evap. } \\
(\mathbf{m m} \\
\left.\text { day }^{-1}\right)\end{array}$} & \multirow[b]{2}{*}{$\begin{array}{l}\text { Rain } \\
\text { mm }\end{array}$} \\
\hline & Max. & Min. & Mean & Max. & Min. & Mean & & & \\
\hline \multicolumn{10}{|c|}{2013 season } \\
\hline April & 26.04 & 15.87 & 20.96 & 74.20 & 43.90 & 59.05 & 1.11 & 5.30 & 8.40 \\
\hline May & 31.43 & 21.85 & 26.64 & 75.03 & 45.78 & 60.41 & 1.20 & 6.35 & 0.00 \\
\hline June & 32.44 & 23.97 & 28.21 & 74.63 & 51.27 & 62.95 & 1.34 & 6.61 & 0.00 \\
\hline July & 32.32 & 24.31 & 28.32 & 79.57 & 54.70 & 67.14 & 1.28 & 6.11 & 0.00 \\
\hline \multicolumn{10}{|c|}{2014 season } \\
\hline April & $\mathbf{2 7 . 5 0}$ & 15.53 & 21.52 & 81.80 & 49.80 & 65.8 & 1.07 & 4.91 & 20.2 \\
\hline May & 30.47 & 19.57 & 25.02 & 77.20 & 48.60 & 62.90 & 1.14 & 5.87 & 0.00 \\
\hline June & 32.65 & 20.60 & 26.63 & 86.23 & 52.30 & 69.27 & 0.95 & 6.56 & 0.00 \\
\hline July & 33.15 & 23.64 & 28.40 & 83.19 & 55.11 & 69.15 & 1.13 & 7.73 & 0.00 \\
\hline
\end{tabular}

Table (2): Particle size distributions, bulk density, some soil-water characters and chemical soil properties of the experimental site (mean of 2013 and 2014 seasons).

\begin{tabular}{|c|c|c|c|c|c|c|c|c|c|c|c|}
\hline \multirow{3}{*}{$\begin{array}{c}\text { Soil } \\
\text { layer } \\
\text { depth } \\
(\mathbf{c m})\end{array}$} & \multirow{2}{*}{\multicolumn{4}{|c|}{ Particle size distribution }} & \multirow{3}{*}{\multicolumn{2}{|c|}{$\begin{array}{c}\text { Textural } \\
\text { class }\end{array}$}} & \multirow{3}{*}{$\begin{array}{c}\text { Bulk } \\
\text { density } \\
\left(\mathbf{K g m}^{-3}\right)\end{array}$} & \multicolumn{4}{|c|}{ Soil- water constant } \\
\hline & & & & & & & & \multirow{2}{*}{$\begin{array}{c}\text { F.C }{ }^{*} \\
(\%, w t / \\
\text { wt })\end{array}$} & \multirow{2}{*}{\multicolumn{2}{|c|}{$\begin{array}{l}\text { P.W.P.** } \\
(\%, w t / w t)\end{array}$}} & \multirow{2}{*}{$\begin{array}{c}\text { A.W } W^{* * *} \\
(\%, w t / w t)\end{array}$} \\
\hline & $\begin{array}{c}\text { Sand } \\
\%\end{array}$ & Silt \% & \multicolumn{2}{|c|}{$\begin{array}{c}\text { Clay } \\
\%\end{array}$} & & & & & & & \\
\hline $0-15$ & 14.90 & 24.40 & \multirow{2}{*}{\multicolumn{2}{|c|}{60.70}} & \multicolumn{2}{|c|}{ Clay } & 1.16 & 43.32 & \multicolumn{2}{|c|}{22.44} & 20.88 \\
\hline $15-30$ & 19.40 & 28.30 & & & \multicolumn{2}{|c|}{ Clay } & 1.20 & 41.00 & \multicolumn{2}{|c|}{21.55} & 19.45 \\
\hline $30-45$ & 22.22 & 27.12 & \multicolumn{2}{|c|}{50.66} & \multicolumn{2}{|c|}{ Clay } & 1.22 & 40.08 & \multicolumn{2}{|c|}{21.18} & 18.90 \\
\hline $45-60$ & 20.88 & 30.66 & \multicolumn{2}{|c|}{48.46} & \multicolumn{2}{|c|}{ Clay } & 1.24 & 39.14 & \multicolumn{2}{|c|}{21.08} & 18.06 \\
\hline Mean & 19.35 & 27.62 & \multicolumn{2}{|c|}{53.03} & \multicolumn{2}{|c|}{ Clay } & 1.20 & 40.88 & \multicolumn{2}{|c|}{21.56} & 19.32 \\
\hline \multicolumn{12}{|c|}{ Chemical Soil characteristics } \\
\hline & \multirow[b]{2}{*}{$\mathbf{P}_{\mathbf{H}}$} & \multirow{2}{*}{$\begin{array}{c}\mathrm{EC} \\
\mathrm{dSm}^{-1}\end{array} \mid$} & \multicolumn{5}{|c|}{ Soluble cations, $\operatorname{meq}^{-1}$} & \multicolumn{4}{|c|}{ Soluble anions, meq $^{-1}$} \\
\hline & & & $\mathbf{C a}^{++}$ & $\mathbf{M g}$ & & $\mathbf{N a}^{+}$ & $\mathbf{K}^{+}$ & $\mathrm{CO}_{3}$ & $\mathrm{HCO}_{3}^{-}$ & $\mathrm{Cl}^{-}$ & $\mathrm{SO}_{4}^{--}$ \\
\hline $0-15$ & 8.15 & 2.44 & 4.50 & 4.8 & 80 & 14.6 & 0.55 & - & 9.10 & 3.40 & $\mathbf{1 1 . 9 5}$ \\
\hline 15-30 & 8.09 & 2.65 & 3.40 & 5. & 90 & 17.0 & 0.26 & - & 9.16 & 9.78 & 7.62 \\
\hline $30-45$ & 8.00 & 3.50 & 5.00 & 6. & & 23.6 & 0.27 & - & 12.70 & 13.75 & 8.63 \\
\hline $45-60$ & 7.90 & 3.49 & 6.70 & 13 & 50 & 14.5 & 0.30 & - & 10.60 & 15.21 & 9.20 \\
\hline Mean & 8.04 & 3.02 & 4.90 & 7. & & 17.4 & 0.35 & - & 10.39 & 10.5 & 9.35 \\
\hline
\end{tabular}

FC $^{*}=$ Field capacity, PWP $* *=$ Permanent wilting point and $\mathbf{A W}^{* * *}=$ Available soil water

Productivity of irrigation water (PIW, $\mathrm{Kg} \mathrm{m}^{-3}$ )

Productivity of irrigation water (PIW) was calculated according to Ali et al., (2007).

Where

$$
P I W=Y / I
$$

PIW = productivity of irrigation water $\left(\mathrm{Kg} \mathrm{m}^{-3}\right)$,

$\mathrm{Y}=$ fruit yield $\mathrm{kg} \mathrm{fed}^{-1}$, and

$\mathrm{I}=$ irrigation water applied $\left(\mathrm{m}^{3} \mathrm{fed}^{-1}\right)$.

2.3.2. Water consumptive use

Soil moisture percentage was determined (on weight basis) just before and 48 hrs after each irrigation as well as at harvest to compute the actual consumed water as stated by Hansen $e t a l$. (1979) as follows:

$$
\mathrm{CU}=\text { S.M.D. }=\sum_{\mathrm{i}=1}^{\mathrm{i}=4} \frac{\phi_{2}-\phi_{1}}{100} \times{ }_{\mathrm{b}}^{\rho} \times \mathrm{D}_{\mathrm{i}}
$$

Where:

$\mathrm{CU}=$ Water consumptive use $(\mathrm{cm})$ in the effective root zone of $60 \mathrm{~cm}$ soil depth

S.M.D. $=$ Soil Moisture Depletion, $\mathrm{cm}$.

$\mathrm{i}=$ Number of soil layer (1-4)

$\mathrm{D}_{\mathrm{i}}=$ Soil layer thickness $(15 \mathrm{~cm})$ 
$\rho_{b}=$ Bulk density $\left(\mathrm{gm} . \mathrm{cm}^{-3}\right)$ of the concerned soil layer.

$\phi_{1}=$ Soil moisture percentage (mass/mass) before irrigation and

$\phi_{2}=$ Soil moisture percentage (mass/mass), 48 hours after irrigation.

\subsubsection{Consumptive use efficiency (Ecu)}

The consumptive use efficiency (Ecu) was calculated as described by Doornbos and Pruitt (1975) as follows:

$$
\mathrm{Ecu}=\frac{\mathrm{ETc}}{\mathrm{Wa}} \times 100
$$

Where:

Ecu efficiency $\%=$ Consumptive use

$$
\text { ETc }=\text { Total }
$$

evapotranspiration $\simeq$ consumptive use $\left(\mathrm{m}^{3} \mathrm{fed}^{-1}\right)$.

$\mathrm{Wa}=$ Water applied to the field $\left(\mathrm{m}^{3} \mathrm{fed}^{-1}\right)$.

2.3.4.Water productivity (WP, $\mathrm{Kg} \mathrm{m}^{-3}$ )

Water productivity is generally defined as crop yield per cubic metre of water consumption. Water productivity can be also defined as crop production per unit amount of water used. Concept of water productivity in agricultural production system is focused on producing more food using the same quantity of water or, producing the same amount of food with less water. Water productivity was calculated according to Ali et al., (2007).

$$
W P=Y / E T
$$

Where:

$\mathrm{WP}=$ water productivity $\left(\mathrm{kg} \mathrm{m}^{-3}\right)$

$\mathrm{Y}=$ fruit yield $\left(\mathrm{kg} \mathrm{fed}^{-1}\right)$.

ET=total water consumption of the growing season $\mathrm{m}^{3} \mathrm{fed}^{-1}$.

\subsection{Crop Measurements and calculations}

* Vegetative growth measurements

- Plant height $(\mathrm{cm})$

- Number of leaves per plant

- Leaf area per plant $\left(\mathrm{dm}^{2}\right)$
- Chlorophyll content $\left(\mathrm{mgdm}^{-2}\right)$ : determined spectrocolorimeterically at 60 days after transplanting as described by Moran and Porath (1982).

* Fruit yield, yield components and quality

- Early fruit yield (yield of first three picking) and total fruit yield (tonfed ${ }^{-1}$ )

- Mean fruit weight (g)

- Vitamin C (mg / $100 \mathrm{~g}$ fresh wt), and

- Total Soluble Solids (TSS \%)

*Mineral content

Nitrogen (\%) was determined in the digestion product using the micro-kjeldahl method (AOAC, 1980). Phosphorus (\%) was determined colorimetrically at $725 \mu \mathrm{m}$ (King, 1951). Potassium (\%) was determined using a flame photometer (Jackson, 1973). Samples were taken at 60 days after transplanting from leaves of the plants.

Data were statistically analyzed according to the technique of analysis of variance (ANOVA) as published by Gomez and Gomez (1984). Means of the treatments were compared using Least Significant Difference (LSD) at 5\% level of significance as developed by Waller and Duncan (1969).

\section{RESULTS AND DISCUSSION \\ 3.1. Effect of irrigation and K-fertilizer forms on:}

3.1.1. Irrigation water applied (IW, $\mathrm{m}^{3} / \mathrm{fed}$.)

Data in Table (3) show the amount of IW applied. Transplanted watering through complete emergence was accompanied with an amount of 480.5 and $502.0 \mathrm{~m}^{3} \mathrm{fed}^{-1}$ in the first and second season, respectively for all treatments. The average seasonal irrigation water values amounted to $1630.5(38.82 \mathrm{~cm})$ and $2053.5 \mathrm{~m}^{3}$ $\mathrm{fed}^{-1}(48.89 \mathrm{~cm})$. The increases in IW by

\begin{tabular}{|c|c|c|c|c|c|c|c|c|c|}
\hline \multirow[b]{2}{*}{ Treatments } & \multicolumn{3}{|c|}{ IW $\left(\mathrm{m}^{3}\right.$ fed $\left.^{-1}\right)$} & \multicolumn{3}{|c|}{ IW (cm.) } & \multicolumn{3}{|c|}{ PIW, $\mathrm{kg} \mathrm{m}^{-3}$} \\
\hline & 2013 & 2014 & $\begin{array}{c}\text { Overall } \\
\text { mean }\end{array}$ & 2013 & 2014 & $\begin{array}{c}\text { Overall } \\
\text { mean }\end{array}$ & 2013 & 2014 & $\begin{array}{c}\text { Overall } \\
\text { mean }\end{array}$ \\
\hline $\begin{array}{c}\text { Trad., irr. } \\
\text { Control }\left(\mathbf{I}_{0}\right)\end{array}$ & 2095.0 & 2012.0 & 2053.5 & 49.88 & 47.90 & 48.89 & 10.09 & 11.04 & 10.57 \\
\hline $\begin{array}{c}\text { Pan evapo. } \\
\left(\mathbf{I}_{1}\right)\end{array}$ & 1800.0 & 1812.0 & 1806.0 & 42.86 & 43.14 & 43.00 & 11.32 & 11.78 & 11.55 \\
\hline $\begin{array}{c}\text { Harg., equ., } \\
\left(\mathbf{I}_{2}\right)\end{array}$ & 1633.0 & 1628.0 & 1630.5 & 38.88 & 38.77 & 38.82 & 10.37 & 10.95 & 10.66 \\
\hline $\begin{array}{c}\text { Ibr., equ. } \\
\left(\mathbf{I}_{3}\right)\end{array}$ & 1700.0 & 1719.0 & 1709.5 & 40.47 & 40.92 & 40.70 & 9.45 & 9.72 & 9.59 \\
\hline
\end{tabular}
traditional irrigation may be due to the fact that

Table (3): Seasonal water applied $\mathrm{m}^{3} \mathrm{Fed}^{-1}, \mathrm{~cm}$ and productivity of irrigation water PIW, $\mathrm{kgm}^{-3}$. 
frequently watered plants used more water because they found it much more easily without suffering from water deficit. These results are in agreement with those obtained by Ertek et al. (2004); for summer squash who stated that if other conditions were equal, roots of plants in wet soil will extract more water than those grown in the dried soil.

\subsubsection{Productivity of irrigation Water (PIW, $\mathrm{kg} \mathrm{m}^{-3}$ )}

The results revealed that the irrigation amount significantly affected PIW values (Table 2). PIW values ranged from 9.45 to $11.32 \mathrm{~kg} \mathrm{~m}^{-3}$ for $I_{3}$ and $I_{1}$ in the first season and 11.78 to 9.72 $\mathrm{kg} \mathrm{m}^{-3}$ for the same treatments in the second one. In general, productivity of irrigation water on fresh yield depends directly on more frequent irrigation application.

\subsubsection{Crop water consumptive use (CU)}

Crop water consumptive use (CU) or crop evapotranspiration $\left(\mathrm{ET}_{\mathrm{c}}\right)$ was computed on the basis of water depletion from the effective root zone of the upper $60 \mathrm{~cm}$ soil depth. Seasonal CU for squash clearly was affected by both irrigation treatments and potassium application forms in the two growing seasons. Concerning the effect of irrigation treatments, the highest values were recorded under irrigation treatments $\mathrm{I}_{0}$ (control) compared with the other treatments $\left(\mathrm{I}_{1}, \mathrm{I}_{2}\right.$ and $\left.\mathrm{I}_{3}\right)$. The highest mean values were 43.58 and $41.30 \mathrm{~cm}$ by the control and $\mathrm{k}_{1}$ treatment, while the lowest were 34.17 and $34.35 \mathrm{~cm}$ ) by $\mathrm{I}_{2}$. These results are in agreements with Ertek et al. (2004). Therefore, using $\mathrm{K}_{1}$ (100\% Potassium mineral fertilizer), was the most efficient potassium forms treatment under all irrigation treatments. Regarding the interaction effect, results in Table (4) show that the effects among the different combinations as the lowest values of $\mathrm{CU}$ were obtained in plants grown under the lowest amount of irrigation water with application of potassium in rock feldspar $\left(\mathrm{I}_{2} \mathrm{~K}_{5}\right)$ in both seasons.

\subsubsection{Consumptive use efficiency (Ecu\%)}

Consumptive use efficiency (Ecu) is a parameter which indicates the capability of plants to utilize the soil moisture stored in the effective root zone. Percentage of Ecu shown in Table (4) show that the highest value of $93.44 \%$ was obtained from $\mathrm{I}_{1}$ (class A pan). Therefore, by decreasing the applied water, higher amount of irrigation water could be beneficially used by the growing plants resulting in decreasing water losses.

\subsubsection{Water productivity, $\left(\mathrm{kg} \mathrm{m}^{-3}\right)$}

Water productivity of squash yield which indicates the capability of one unit of consumed water in crop production was affected by both the water applied and the potassium fertilizer forms (Table 4). Under traditional irrigation, values of WP for squash as tabulated in Table (3) can be arranged in a descending order: 12.48 $>12.40>12.32>12.29>12.25 \mathrm{~kg} \mathrm{~m}^{-3}$ consumed for $\mathrm{I}_{1} \mathrm{~K}_{5}, \mathrm{I}_{1} \mathrm{~K}_{2}, \mathrm{I}_{1} \mathrm{~K}_{4}, \mathrm{I}_{1} \mathrm{~K}_{3}$ and $\mathrm{I}_{1} \mathrm{~K}_{1}$ treatments, respectively. On the other hand, the least values were recorded with Ibrahim; equation and the values can be arranged in a descending order of: $10.85>10.84>10.58>$ $10.56>10.52 \mathrm{~kg} \mathrm{~m}^{-3}$ consumed for $\mathrm{I}_{3} \mathrm{~K}_{5}, \mathrm{I}_{3} \mathrm{~K}_{2}$, $\mathrm{I}_{3} \mathrm{~K}_{4}, \mathrm{I}_{3} \mathrm{~K}_{3}$ and $\mathrm{I}_{3} \mathrm{~K}_{1}$ treatments, respectively. These results are in agreement with those of AlOmran et al. (2005) who indicated that water use efficiency was higher under higher water applied conditions (100 and $120 \%$ of ETo) compared to less water applied conditions (60 and $80 \%$ of ETo). On the contrary, Ertek et al. (2004) obtained the highest irrigation water use efficiency (IWUE) values for summer squash under the lowest irrigation conditions (45\% of Class A pan evaporation).

The linear regression equations between irrigation water applied, $\mathrm{cm}$ and potassium fertilizer forms on consumptive use, $\mathrm{cm}$ are shown in Fig. (1).These equations show that, the relationship between applied irrigation water quantities and consumptive use, $\mathrm{cm}$ is more reliable in the two seasons.

\subsection{Effect of irrigation and K-fertilizers forms application on \\ 3.2.1. Vegetative parameters}

Data listed in Table (5) show that irrigation water treatments caused significant effect on all vegetable growth parameters in both summer seasons; shoots fresh and dry weight, gm per plant, plant height and plant leaf area had the highest mean values under treatment $\mathrm{I}_{0}$ (traditional irrigation) in comparison with $\mathrm{I}_{1}, \mathrm{I}_{2}$ and $I_{3}$. The mean values were 956.8 and 966.0 g., for shoots fresh weight, 171.2 and $173.2 \mathrm{~g}$., for dry shoots weight, 66.9 and $68.9 \mathrm{~cm}$ for plant height, 25.3 and 24.9 for the number of leaves/ plant and 2867.2 and $2820.8 \mathrm{~cm}^{2}$ for leaf area/ plant in the first and second seasons, respectively.

Meanwhile, the lowest mean values for the above mentioned studied parameters were recorded under irrigation with $\mathrm{I}_{3}$ (Ibr. Equ.) and 
Table (4): Consumptive use (cm), consumptive use efficiency (Ecu) and water productivity $\left(\mathrm{WP}, \mathrm{Kg} \mathrm{m}^{-3}\right.$ ) as affected by irrigation and $\mathrm{K}-$ fertilizer in both seasons.

\begin{tabular}{|c|c|c|c|c|c|c|c|c|c|c|}
\hline \multirow{2}{*}{\multicolumn{2}{|c|}{ Treatments }} & \multicolumn{3}{|c|}{$\mathrm{CU}(\mathrm{cm})$} & \multicolumn{3}{|c|}{ Ecu $(\%)$} & \multicolumn{3}{|c|}{$\mathrm{WP}, \mathrm{kg} \mathrm{m}^{-3}$} \\
\hline & & \multirow{2}{*}{$\begin{array}{r}2013 \\
44.05\end{array}$} & \multirow{2}{*}{$\begin{array}{r}2014 \\
41.70\end{array}$} & \multirow{2}{*}{$\begin{array}{c}\text { Overa } \\
\text { ll } \\
\text { mean }\end{array}$} & \multirow{2}{*}{$\begin{array}{r}2013 \\
88.31\end{array}$} & \multirow{2}{*}{$\begin{array}{r}2014 \\
87.06\end{array}$} & \multirow{2}{*}{$\begin{array}{c}\begin{array}{c}\text { Overal } \\
\text { I mean }\end{array} \\
87.69\end{array}$} & \multirow{2}{*}{$\begin{array}{r}2013 \\
11.43\end{array}$} & \multirow{2}{*}{$\begin{array}{r}2014 \\
12.68\end{array}$} & \multirow{2}{*}{$\begin{array}{c}\begin{array}{c}\text { Overall } \\
\text { mean }\end{array} \\
12.06\end{array}$} \\
\hline \multirow{6}{*}{ 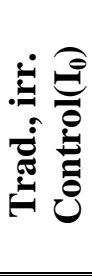 } & $\mathrm{K}_{1}$ & & & & & & & & & \\
\hline & $\mathbf{K}_{2}$ & 43.20 & 41.00 & 42.10 & 86.61 & 85.59 & 86.10 & 11.65 & 12.90 & 12.28 \\
\hline & $\mathbf{K}_{3}$ & 43.88 & 41.50 & 42.69 & 87.97 & 86.64 & 87.31 & 11.47 & 12.75 & .11 \\
\hline & $K_{4}$ & 43.80 & 41.38 & 42.59 & 87.81 & 86.39 & 87.10 & 11.49 & 12.78 & 13 \\
\hline & $\mathrm{K}_{5}$ & 42.99 & 40.90 & 41.95 & 86.19 & 85.39 & 85.79 & 11.71 & 12.93 & 12.32 \\
\hline & Mean & 43.58 & 41.30 & 42.44 & 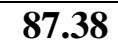 & 86.21 & 86.80 & 11.55 & 12.81 & 12.18 \\
\hline \multirow{6}{*}{ 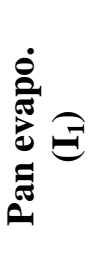 } & & 40.68 & 40. & 40.56 & 94. & 2 & & 11.92 & 7 & 25 \\
\hline & $\mathbf{K}_{2}$ & 40.13 & 40.00 & 40.06 & 93. & 0 & 1 & 12.09 & 12 & 40 \\
\hline & $\mathbf{K}_{3}$ & 40.47 & 40.35 & 40.41 & 94.42 & 3.53 & 93.86 & 11.98 & 12.60 & 29 \\
\hline & $K_{4}$ & 40.35 & 40.25 & 40.30 & 94.14 & 93.30 & 72 & 12.02 & 12.63 & 32 \\
\hline & $K_{5}$ & 39.87 & 39.70 & 39.78 & $\mathbf{9 3 . 0 2}$ & 92.42 & 92.72 & 12.16 & 12.80 & 12.48 \\
\hline & Mean & 40.30 & 40.14 & 40.22 & 94.02 & 93.01 & 93.44 & 12.03 & 12.66 & 12.35 \\
\hline \multirow{6}{*}{ 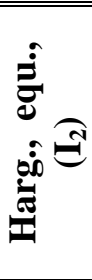 } & $\mathbf{K}_{1}$ & 34.65 & 34.90 & 34.77 & 89.76 & 90.01 & 89.89 & 11.64 & 12.16 & 11.90 \\
\hline & $\mathbf{K}_{2}$ & 33.70 & 33.90 & 33.80 & 86.68 & 87.43 & 87.06 & 11.97 & 12.52 & 12.25 \\
\hline & $\mathbf{K}_{3}$ & 33.50 & 34.64 & 34.57 & 86.16 & 89.34 & 87.75 & 12.04 & 12.25 & 12.15 \\
\hline & $\mathbf{K}_{4}$ & 34.42 & 34.46 & 34.44 & 88.53 & $\mathbf{8 8 . 8 8}$ & 88.70 & 11.72 & 12.31 & 12.01 \\
\hline & $K_{5}$ & 33.60 & 33.85 & $\mathbf{3 3 . 7 3}$ & 86.42 & 87.31 & 86.87 & 12.00 & 12.53 & 12.27 \\
\hline & Mean & 34.17 & 34.35 & 34.26 & 87.51 & 88.59 & 88.05 & 11.87 & 12.35 & 12.11 \\
\hline \multirow{6}{*}{ 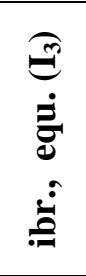 } & $K_{1}$ & 37.35 & 36.85 & 37.10 & 92.29 & 90.05 & 91.17 & 10.24 & 10.80 & 10.52 \\
\hline & $\mathbf{K}_{2}$ & 36.18 & 35.80 & 35.99 & 89.39 & 87.48 & 88.44 & 10.57 & 11.11 & 10.84 \\
\hline & $\mathbf{K}_{3}$ & 37.20 & 36.70 & 36.95 & 91.92 & 89.69 & 90.81 & 10.28 & 10.84 & 10.56 \\
\hline & $\mathbf{K}_{4}$ & 37.18 & 36.60 & 36.89 & 91.87 & 89.44 & 90.66 & 10.28 & 10.87 & 10.58 \\
\hline & $\mathbf{K}_{5}$ & 36.30 & 35.65 & 35.98 & 89.70 & 87.12 & 88.41 & 10.53 & 11.16 & 10.85 \\
\hline & Mean & 36.84 & 36.38 & \begin{tabular}{|l|}
36.61 \\
\end{tabular} & $\begin{array}{l}91.03 \\
\end{array}$ & 88.76 & 89.89 & $\begin{array}{l}10.38 \\
\end{array}$ & 10.95 & $\begin{array}{c}10.67 \\
\end{array}$ \\
\hline
\end{tabular}

$K_{1}: 100 \%$ Potassium mineral fertilizer, $K_{2}: 75 \%$ Potassium mineral fertilizer and $25 \%$ Rock feldspar, $K_{3}: 50 \%$ Potassium mineral fertilizer and $50 \%$ Rock feldspar, $K_{4}: 25 \%$ Potassium mineral fertilizer and $75 \%$ Rock feldspar and $\mathrm{K}_{5}: 100 \%$ Rock feldspar
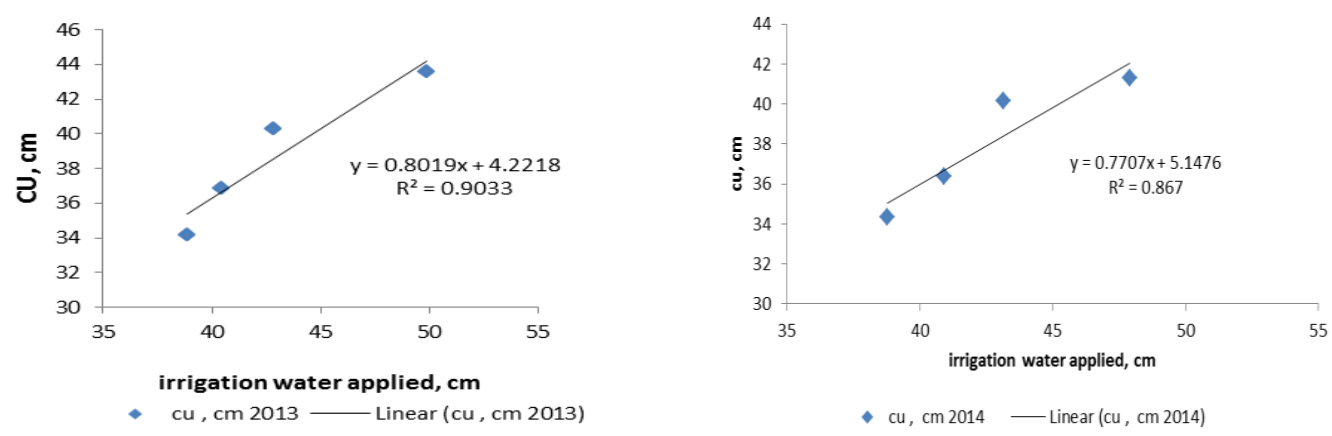

Fig. (1): Correlation between irrigation water applied, $\mathrm{cm}$ overall potassium fertilizer on consumptive use, $\mathrm{cm}$ (plant water consumption) in the two growing seasons. 
Table (5): Effect of irrigation water applied and K-fertilization forms on shoot fresh weight (g), shoot dry weight $(\mathrm{g})$, plant height $(\mathrm{cm})$, no of leaves/ plant and leaf area /plant $\left(\mathrm{cm}^{2}\right)$ in the two growing seasons.

\begin{tabular}{|c|c|c|c|c|c|c|c|c|c|c|c|}
\hline \multirow{2}{*}{\multicolumn{2}{|c|}{ Treatments }} & \multicolumn{2}{|c|}{$\begin{array}{l}\text { Shoot fresh } \\
\text { weight(g) }\end{array}$} & \multicolumn{2}{|c|}{$\begin{array}{l}\text { Shoot dry } \\
\text { weight }(g)\end{array}$} & \multicolumn{2}{|c|}{$\begin{array}{c}\text { Plant height } \\
\text { (cm) }\end{array}$} & \multicolumn{2}{|c|}{$\begin{array}{c}\text { No of leaves/ } \\
\text { plant }\end{array}$} & \multicolumn{2}{|c|}{$\begin{array}{c}\text { Leaf area } \\
/ \text { plant }\left(\mathrm{cm}^{2}\right)\end{array}$} \\
\hline & & 2013 & 2014 & 2013 & 2014 & 2013 & 2014 & 2013 & 2014 & 2013 & 2014 \\
\hline \multirow{6}{*}{ 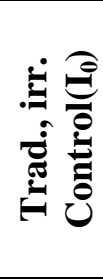 } & $\mathrm{K}_{1}$ & \begin{tabular}{|l|}
963.7 \\
\end{tabular} & 972.5 & 172.8 & 174.0 & 67.8 & 69.9 & 24.5 & 25.9 & 2988.3 & 2872.0 \\
\hline & $\mathrm{K}_{2}$ & 947.5 & 961.3 & 169.5 & 172.3 & 66.0 & 68.1 & 21.9 & 24.1 & 2758.8 & 2782.3 \\
\hline & $\mathrm{K}_{3}$ & \begin{tabular}{|l|}
975.0 \\
\end{tabular} & 976.3 & 174.3 & 176.5 & 68.7 & 71.3 & 25.3 & 26.6 & 3042.0 & 2933.5 \\
\hline & $\mathrm{K}_{4}$ & 961.3 & 963.8 & 171.0 & 173.5 & 67.7 & 68.4 & 23.6 & 24.9 & 2881.5 & 2810.3 \\
\hline & $\mathrm{K}_{5}$ & 936.3 & 956.3 & 168.5 & 169.8 & 64.5 & 67.0 & 21.0 & 23.3 & 2665.5 & 2705.8 \\
\hline & Mean & 956.8 & 966.0 & 171.2 & 173.2 & 66.9 & 68.9 & 25.3 & 24.9 & 2867.2 & 2820.8 \\
\hline \multirow{6}{*}{ 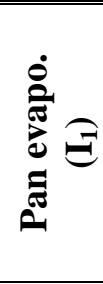 } & $\mathbf{K}_{1}$ & 918.8 & 961.3 & 168.5 & 171.0 & $\begin{array}{l}63.3 \\
\end{array}$ & 66.0 & 21.8 & 23.9 & 2686.5 & 95.5 \\
\hline & $\mathbf{K}_{2}$ & 890.0 & 956.3 & 165.5 & 168.5 & 60.9 & 63.7 & 20.6 & 22.6 & 2523.3 & $\mathbf{1 9 1 7 . 8}$ \\
\hline & $\mathbf{K}_{3}$ & 931.3 & 962.5 & 169.5 & 171.5 & 64.5 & 67.5 & 22.8 & 24.3 & 2769.5 & 2040.8 \\
\hline & $\mathrm{K}_{4}$ & 912.5 & 958.3 & 166.8 & 170.0 & 61.5 & 65.3 & 20.6 & 23.3 & 2594.8 & 1968.5 \\
\hline & $\mathbf{K}_{5}$ & 870.0 & 951.3 & 164.3 & 166.0 & 59.9 & 62.0 & 19.8 & 21.8 & 2489.0 & 32.5 \\
\hline & Mean & 904.5 & 957.9 & 166.9 & 169.4 & 62.0 & 64.9 & 21.1 & 23.2 & 2612.6 & 61.0 \\
\hline \multirow{6}{*}{ 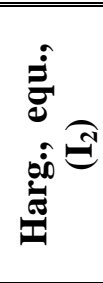 } & $\mathbf{K}_{1}$ & 867.5 & 933.8 & 164.0 & 167.5 & 59.7 & 61.8 & 20.2 & 22.1 & 2244.5 & 1817.8 \\
\hline & $\mathrm{K}_{2}$ & 837.5 & 905.0 & 157.5 & 160.3 & 56.6 & 58.6 & 18.9 & 20.8 & 2144.0 & $\mathbf{1 7 7 1 . 8}$ \\
\hline & $\mathrm{K}_{3}$ & \begin{tabular}{|l|}
890.0 \\
\end{tabular} & 951.3 & 165.3 & 168.3 & 61.0 & 63.0 & 21.3 & 22.8 & 2394.3 & 1851.7 \\
\hline & $\mathrm{K}_{4}$ & 852.5 & 918.4 & 159.0 & 164.5 & $\begin{array}{l}57.8 \\
\end{array}$ & 60.8 & 19.3 & 21.3 & 2186.5 & $\mathbf{1 7 8 9 . 3}$ \\
\hline & $\mathrm{K}_{5}$ & 815.0 & 897.5 & 152.3 & 158.3 & 55.9 & 57.0 & 18.0 & 20.0 & 2052.3 & $\mathbf{1 7 6 6 . 5}$ \\
\hline & Mean & 852.5 & 921.2 & 159.6 & 163.8 & 58.2 & 60.3 & 19.5 & 21.4 & 2204.3 & $\mathbf{1 7 9 9 . 4}$ \\
\hline \multirow{6}{*}{ 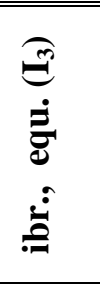 } & $\mathrm{K}_{1}$ & 813.8 & 867.5 & 141.3 & 153.3 & 56.1 & 56.0 & 19.4 & 20.8 & 1977.7 & 1720.8 \\
\hline & $K_{2}$ & 795.0 & 855.0 & 135.5 & 141.7 & 53.9 & 54.4 & 18.0 & 19.7 & 1844.3 & 1684.3 \\
\hline & $\mathrm{K}_{3}$ & 826.3 & 890.0 & 148.0 & 158.3 & 56.9 & 58.2 & 19.8 & 21.4 & 2040.3 & $\mathbf{1 7 5 8 . 5}$ \\
\hline & $\mathrm{K}_{4}$ & 805.0 & 855.0 & 137.0 & 148.8 & 54.9 & 54.9 & 18.6 & 20.0 & 1886.3 & 1700.5 \\
\hline & $\mathrm{K}_{5}$ & $\mathbf{7 7 8 . 8}$ & 831.3 & $\mathbf{1 3 3 . 3}$ & 138.5 & 53.9 & 52.5 & 17.0 & 18.7 & 1687.5 & 1611.0 \\
\hline & Mean & 803.8 & 859.8 & 139.0 & 148.1 & 55.1 & 55.2 & 18.6 & 20.1 & $\mathbf{1 8 8 7 . 2}$ & 1695.0 \\
\hline \multicolumn{2}{|c|}{ LSD 0.05 } & \begin{tabular}{|l|}
9.079 \\
\end{tabular} & 7.834 & 1.782 & 1.570 & $0 . \mathbf{0 . 3 8 3}$ & $\overline{1.003}$ & $\begin{array}{l}\mathbf{0 . 7 9 5} \\
\end{array}$ & \begin{tabular}{|l|l|}
$\mathbf{0 . 8 4 3}$ \\
\end{tabular} & $\mathbf{3 1 . 0 2 5}$ & 21.461 \\
\hline \multirow{3}{*}{$\underbrace{5}_{5}$} & I & $* * *$ & $* * *$ & **** & $* * *$ & $* * *$ & $* * *$ & $* * *$ & $* * *$ & $* * *$ & $* * *$ \\
\hline & $\mathbf{K}$ & $* *$ & $* *$ & $* * *$ & $* * *$ & $* * *$ & $* * *$ & $* * *$ & $* * *$ & $* * *$ & $* * * *$ \\
\hline & $\mathbf{I} * \mathbf{K}$ & $* * *$ & $* * *$ & $* * *$ & $* * *$ & $* *$ & NS & $* *$ & NS & $* *$ & $* *$ \\
\hline
\end{tabular}

$*, * *, * * *$ and NS: significant at $\mathbf{p} \leq 0.05,0.01,0.001$ or not significant, respectively.

Means separated at $\mathbf{P} \leq \mathbf{0 . 0 5}$, LSD test.

$K_{1}: 100 \%$ Potassium mineral fertilizer, $K_{2}: 75 \%$ Potassium mineral fertilizer and $25 \%$ Rock feldspar, $K_{3}$ : $50 \%$ Potassium mineral fertilizer and $50 \%$ Rock feldspar, $K_{4}: 25 \%$ Potassium mineral fertilizer and $75 \%$ Rock feldspar and $K_{5}: 100 \%$ Rock feldspar

the mean values were 803.8 and $859.8 \mathrm{~g}$., for shoot fresh weight, 139.0 and $148.1 \mathrm{~g}$., for shoot dry weight, 55.1 and $55.2 \mathrm{~cm}$ for plant height, 18.6 and 20.1for the number, of leaves / plant and 1887.2 and $1695.0 \mathrm{~cm}^{2}$ for leaf area / plant in the first and second seasons respectively. Generally, the mean values of the above mentioned studied parameters can be averaged and arranged in decreasing order to $\mathrm{I}_{0}$ (Trad.,) Irr.,> $\mathrm{I}_{1}$ (Pan eva.,)> $\mathrm{I}_{3}$ (Harg., equ.,)> $\mathrm{I}_{4}$ (Ibr., equ.,). These results may be due to the effect of increasing irrigation water on increasing the absorption of some nutrient elements (Ibrahim and Selim, 2007), which improved photosynthetic capacity operation in leaves, and this in turn led to enhancement of the plant growth.

Regarding the effect of K-fertilizer forms on these parameters the results indicated significant effect for potassium forms under all irrigation treatments. The highest mean values were recorded under treatment $\mathrm{K}_{3}(50 \% \mathrm{M} \mathrm{K} \mathrm{F}+50$ $\%$ rock feldspar) in comparison with the other $\mathrm{K}$ treatments $\mathrm{K}_{1}, \mathrm{~K}_{2}, \mathrm{~K}_{4}$ and $\mathrm{K}_{5}$. In this concern Asmaa and Magda (2010) found that the vegetative growth parameters i.e. plant length, 

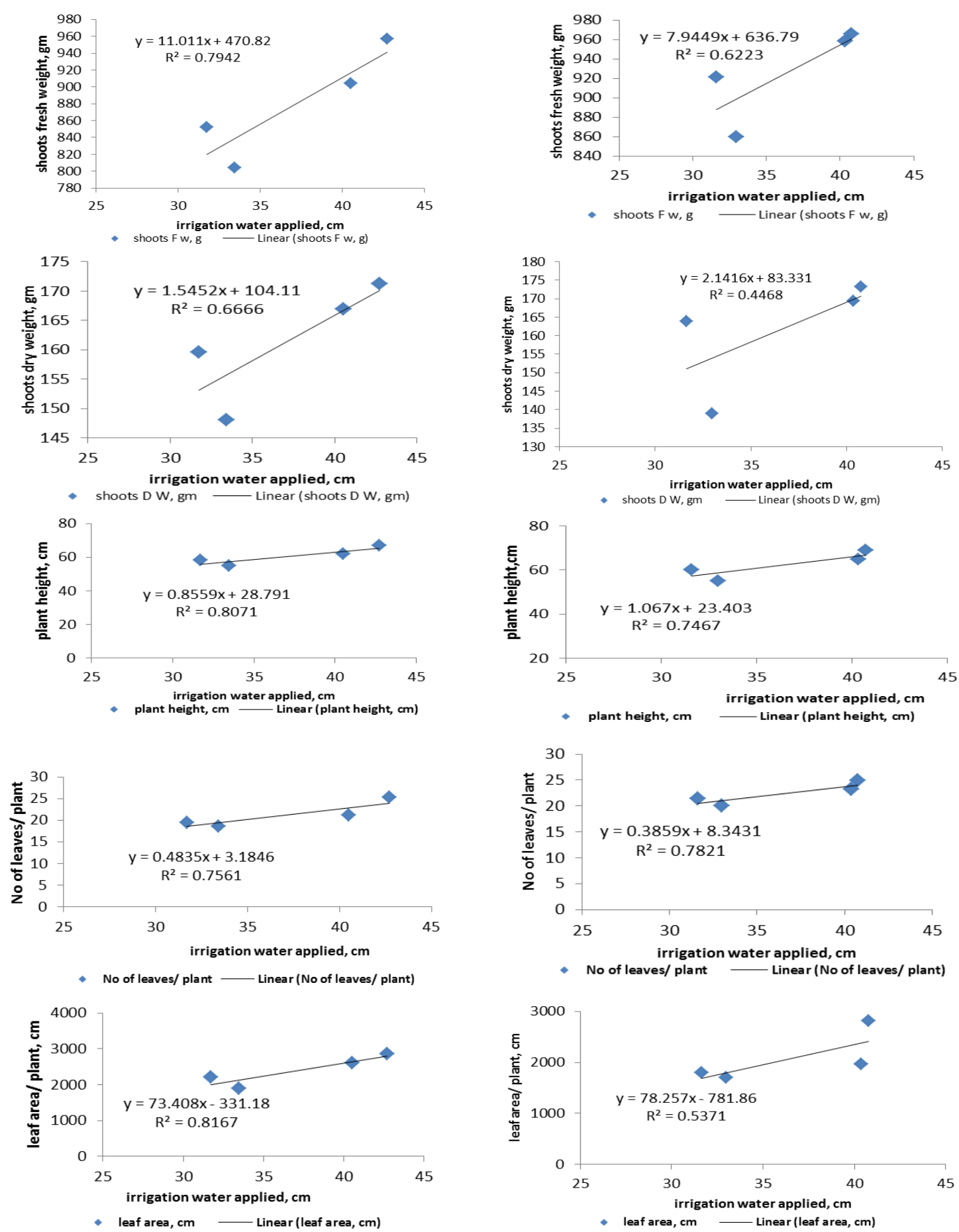

Fig. (2): Correlation between irrigation water applied, $\mathrm{cm}$ overall potassium fertilizer on shoots fresh weight $(\mathrm{g})$, shoots dry weight $(\mathrm{g})$, plant height $(\mathrm{cm})$, no. of leaves/ plant and leaf area /plant $\left(\mathrm{cm}^{2}\right)$ in the two growing seasons.

and dry weight of leaves and shoots were gradually and significantly increased by increasing the level of potassium application from 40,80 up to $120 \mathrm{~kg} \mathrm{K2O/fed.,} \mathrm{easily}$ available form $\mathrm{K}$.

The interaction between irrigation water treatments and forms of potassium fertilizer caused significant effect. Plants watered by $\mathrm{I}_{0}$ (traditional irrigation) and adding K-fertilizers (50\%: 50\%) gave the highest values for fresh and dry weight per plant. The lowest values were recorded under $\mathrm{I}_{3}$ (Ibra., equ.,) and adding $\mathrm{K}$ fertilizers (100\% Rock feldspar) and other in between.In this connection, $\operatorname{Brag}(1972)$; pointed 
out that the lower water loss of plants well supplied with $\mathrm{K}$ was due to a reduction in transpiration rate, which not only depends on the osmotic potential of the mesophyll cells but was also controlled to a large extent by the opening and closing of stomata.

From the above illustrated that, irrigation water amount and potassium forms show significant relations to all vegetative parameters; shoot fresh weight $(\mathrm{g})$, shoot dry weight $(\mathrm{g})$, plant height $(\mathrm{cm})$, no of leaves/ plant and leaf area /plant $\left(\mathrm{cm}^{2}\right.$.

\subsubsection{Yield and its components}

For squash, the first three pickings were considered as the early yield. This yield normally is assigned with the higher price. Data presented in Table (6) reveal that increasing irrigation water caused significant increases in weight of the fruit, total fruit yield and early fruit yield in the two summer seasons.

Irrigation with $\mathrm{I}_{0}$ maximized squash yield and its component with the highest value 137.9 and $147.8 \mathrm{gm}$., for weight of fruit and 5.58 and 5.90 ton fed ${ }^{-1}$., for early yield and 21.14 and 22.22 ton $\mathrm{fed}^{-1}$., for total yield. On the other hand, the lowest value 107.0 and $116.7 \mathrm{~g}$., for weight of fruit and 4.26 and 4.45 ton fed $^{-1}$., for early yield and 16.06 and 16.71 ton $\mathrm{fed}^{-1}$., for total yield which yielded from the irrigation water applied of $\mathrm{I}_{3}$.

The results obtained from this study show that when the squash crop is given its full water requirement, 427.3 and $407.6 \mathrm{~mm}$ of water is required in the first and second seasons respectively, but a figure of 317.28 and 316.19 $\mathrm{mm}$ is required when deficit irrigation resulted in saving water of $21.72 \%\left(\approx 462.0 \mathrm{~m}^{3} \mathrm{fed}^{-1}\right.$., $)$ and $19.1 \%\left(\approx 384.0 \mathrm{~m}^{3} \mathrm{fed}^{-1}\right.$., $)$ of the crop water

Table (6): Effect of irrigation water applied and potassium fertilization forms on fruit weight (g), early and total yield $\left(\right.$ ton $\left.\mathrm{fed}^{-1}\right)$, vitamin $\mathrm{C}\left(\mathrm{mg} 100 \mathrm{~g}^{-1}\right.$ fresh wt.) and TSS\%.

\begin{tabular}{|c|c|c|c|c|c|c|c|c|c|c|c|}
\hline \multirow{2}{*}{\multicolumn{2}{|c|}{ Treatments }} & \multicolumn{2}{|c|}{$\begin{array}{c}\text { Fruit } \\
\text { Weight (g.) }\end{array}$} & \multicolumn{2}{|c|}{$\begin{array}{c}\text { Early yield } \\
\left.\text { (tonfed }^{-1}\right)\end{array}$} & \multicolumn{2}{|c|}{$\begin{array}{l}\text { Total Yield } \\
\left(\text { tonfed }^{-1}\right)\end{array}$} & \multicolumn{2}{|c|}{$\begin{array}{c}\text { Vitamin C } \\
\left(\text { mg100g }^{-1} \text { fresh }\right. \\
\text { wt.) }\end{array}$} & \multicolumn{2}{|c|}{$\begin{array}{c}\text { TSS } \\
\%\end{array}$} \\
\hline & & 2013 & 2014 & 2013 & 2014 & 2013 & 2014 & 2013 & 2014 & 2013 & 2014 \\
\hline \multirow{6}{*}{ 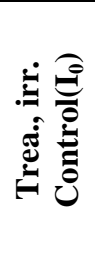 } & $\mathrm{K}_{1}$ & 141.8 & 152.5 & 5.61 & 5.98 & 21.23 & 22.60 & 14.80 & 14.78 & 4.90 & 4.55 \\
\hline & $\mathrm{K}_{2}$ & 132.5 & 142.5 & 5.49 & 5.71 & 20.71 & 21.56 & 13.37 & 13.52 & 4.75 & 4.05 \\
\hline & $\mathrm{K}_{3}$ & 149.5 & 160.0 & 5.90 & 6.28 & 22.65 & 23.55 & 15.20 & 15.60 & 4.92 & 4.67 \\
\hline & $\mathrm{K}_{4}$ & 138.3 & 147.5 & 5.64 & 5.84 & 21.33 & 22.04 & 14.32 & 14.23 & 4.83 & 4.23 \\
\hline & $\mathrm{K}_{5}$ & 127.5 & 136.3 & 5.25 & 5.67 & 19.80 & 21.37 & 13.37 & 13.22 & 4.69 & 3.98 \\
\hline & Mean & 137.9 & 147.8 & $\begin{array}{c}5.58 \\
\end{array}$ & 5.90 & 21.14 & 22.22 & 14.21 & 14.27 & 4.82 & 4.30 \\
\hline \multirow{6}{*}{ 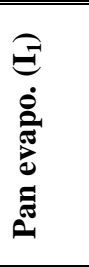 } & $\mathrm{K}_{1}$ & 131.8 & 147.5 & 5.38 & 5.75 & 20.34 & 21.69 & 14.00 & 14.07 & 4.69 & 4.20 \\
\hline & $\mathrm{K}_{2}$ & 123.3 & 136.3 & 5.25 & 5.49 & 19.85 & 20.70 & 13.00 & 13.02 & 4.62 & 3.97 \\
\hline & $\mathrm{K}_{3}$ & 136.3 & 152.5 & 5.72 & 6.04 & 21.75 & 22.76 & 14.97 & 14.90 & 4.75 & 4.40 \\
\hline & $\mathrm{K}_{4}$ & 128.8 & 142.5 & 5.49 & 5.58 & 20.69 & 21.05 & 13.97 & 14.0 & 4.66 & 4.05 \\
\hline & $\mathrm{K}_{5}$ & 118.2 & 132.5 & 5.08 & 5.44 & 19.21 & 20.53 & 12.50 & 12.92 & 4.58 & 3.77 \\
\hline & "Mean & 127.7 & 142.3 & "5.38 & $\overline{5.66}$ & $\begin{array}{l}20.37 \\
\end{array}$ & 21.35 & 13.69 & $\begin{array}{l}13.78 \\
\end{array}$ & 4 4.66 & "4.08 \\
\hline \multirow{6}{*}{ 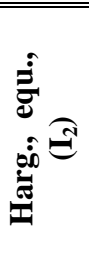 } & $\overline{K_{1}}$ & 124.3 & 137.5 & "4.50 & $\bar{~} 4.80$ & 1717.00 & 18.09 & 13.15 & 13.25 & 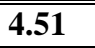 & "4.00 \\
\hline & $\mathbf{K}_{2}$ & 114.3 & 125.0 & 4.39 & 4.58 & 16.59 & 17.26 & 12.13 & 12.02 & 4.32 & 3.90 \\
\hline & $\mathrm{K}_{3}$ & 128.3 & 143.8 & 4.82 & 5.03 & 18.18 & 18.97 & 14.40 & 14.45 & 4.56 & 4.10 \\
\hline & $\mathrm{K}_{4}$ & 118.8 & 131.1 & 4.52 & 4.68 & 17.08 & 17.65 & 12.95 & 13.20 & 4.45 & 3.83 \\
\hline & $\mathrm{K}_{5}$ & 108.8 & 122.5 & 4.20 & 4.54 & 15.83 & 17.13 & 11.18 & 11.93 & 4.26 & 3.40 \\
\hline & Mean & 118.9 & 132.0 & 4.49 & 4.73 & 16.94 & 17.82 & 12.76 & 12.97 & 4.42 & 3.86 \\
\hline \multirow{6}{*}{ 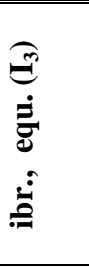 } & $\overline{K_{1}}$ & 111.3 & 125.0 & 4.23 & 4.49 & 15.94 & 16.95 & 12.15 & 12.17 & 4.14 & 3.88 \\
\hline & $\mathrm{K}_{2}$ & 103.8 & 115.0 & 4.32 & 4.29 & 16.29 & 16.19 & 11.27 & 11.05 & 3.95 & 3.53 \\
\hline & $\mathrm{K}_{3}$ & 115.0 & 132.5 & 4.52 & 4.70 & 17.04 & 17.76 & 14.3 & 13.57 & 4.22 & 3.95 \\
\hline & $\mathrm{K}_{4}$ & 107.3 & 121.3 & 4.24 & 4.48 & 16.01 & 16.57 & 12.17 & 12.20 & 4.05 & 3.45 \\
\hline & $\mathrm{K}_{5}$ & 97.5 & 107.5 & 3.98 & 4.27 & 15.02 & 16.08 & 10.85 & 10.35 & 3.79 & 2.75 \\
\hline & Mean & 107.0 & 116.7 & 4.26 & 4.45 & 16.06 & 16.71 & 12.15 & 11.87 & 4.03 & 3.51 \\
\hline \multicolumn{2}{|c|}{ LSD 0.05} & 3.462 & 4.272 & 0.165 & $\begin{array}{c}0.002 \\
\end{array}$ & 0.185 & $\begin{array}{c}0.017 \\
\end{array}$ & 0.420 & 0.319 & $\begin{array}{l}0.032 \\
\end{array}$ & 0.136 \\
\hline \multirow{3}{*}{ 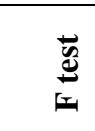 } & I & $* * *$ & $* * *$ & $* * *$ & $* * *$ & $* * *$ & $* * *$ & $* * *$ & $* * *$ & $* * *$ & $* * *$ \\
\hline & $K$ & $* *$ & $* * *$ & $* * *$ & $* * *$ & $* * *$ & $* * *$ & $* * *$ & $* * *$ & $* * *$ & $* * *$ \\
\hline & $\mathbf{I} * \mathbf{K}$ & NS & NS & NS & $*$ & NS & $*$ & $* * *$ & $* * *$ & $* * *$ & $* *$ \\
\hline
\end{tabular}

$*, * *, * * *$ and NS: significant at $\mathbf{p} \leq \mathbf{0 . 0 5}, 0.01,0.001$ or not significant, respectively. Means separated at $\mathrm{P} \leq 0.05, \mathrm{LSD}$ test.

$K_{1}: 100 \%$ Potassium mineral fertilizer, $K_{2}: 75 \%$ Potassium mineral fertilizer and $25 \%$ Rock feldspar, $K_{3}: 50 \%$ Potassium mineral fertilizer and 50\% Rock feldspar, $K_{4}: 25 \%$ Potassium mineral fertilizer and $75 \%$ Rock feldspar and $K_{5}: 100 \%$ Rock feldspar 
requirement is applied in the two seasons with a reduction in fresh yield $(\approx 19.8 \%$ and $19.8 \%)$ compared with the local or traditional irrigation. These findings are in agreement with those of Amer (2011) who found that squash yield, fruit weight, were significantly decreased by the reduction of applied irrigation water. Ertek et al. (2004) concluded that irrigation quantities had significant effects on yield and yield components of summer squash and relationships between the yield and yield components with irrigation water amount were positively linear. Dogan et al. (2008) and Cabello et al. (2009) on melon revealed that decreasing irrigation intervals caused significant increases in total fruit yield and marketable yield in the two summer seasons.

Data in Table (6) revealed that irrigation treatments had little effect on V.C. Irrigation with traditional irrigation $\left(\mathrm{I}_{0}\right)$, maximized V.C. with the highest values of 14.21 and 14.27 $\mathrm{mg} 100 \mathrm{~g}^{-1}$ fresh wt. On the other hand, the least values of 12.76 and $12.97 \mathrm{mg} 100 \mathrm{~g}^{-1}$ fresh wt. were obtained from irrigation water applied depending upon Ibrahim equation.

Data in Table (6) indicated that TSS\% was significantly influenced due to water applied. The highest TSS\% (4.82 and 4.30\%, in $1^{\text {st }}$ and $2^{\text {nd }}$ seasons) were obtained with traditional irrigation, respectively. Total soluble solids\% tended to decrease when irrigation water decreased and the lowest values (4.03 and $3.51 \%$, in the $1^{\text {st }}$ and the $2^{\text {nd }}$ seasons) were recorded under $\mathrm{I}_{3}$ (Ibra., equ.,).

K-fertilizer forms had significant effects on yield and its quality. However, the significantly high values were achieved with $\mathrm{K}_{3}(50 \%$ mineral and $50 \%$ feldspar rock) under all irrigation treatments. Yield and quality exhibited lower values under other K-fertilizers forms and can be arranged in this descending order: $\mathrm{K}_{3}>\mathrm{K}_{4}>\mathrm{K}_{1}>$ $\mathrm{K}_{2}>\mathrm{K}_{5}$ under different irrigation treatments. In this study, the application of multiproduct increased vegetative growth parameters, yield and its components of squash plant. This positive effect may be by providing more nutrients of potassium for the plants which reflected on different plant physiological process. $\mathrm{K}$ is essential for photosynthesis and translocation of photoassimilates (Barker and Pilbeam, 2000).

Regarding the interaction effect between irrigation and $\mathrm{K}$-fertilization treatments, it is clearly noticed that plants irrigated with traditional irrigation and fertilized with $\mathrm{K}_{3}(50 \%$ mineral and 50\% feldspar rock ) in most cases produced the maximum weight of fruit, early and total yield per fed, vitamin C $\left(\mathrm{mg} 100 \mathrm{~g}^{-1}\right.$ fresh wt.) and TSS\%.in both seasons.

Data in Fig. (3) and the concomitant equations reveal that yield and its components are positively correlated with irrigation water amounts and adding potassium forms. The correlation coefficient values were 0.7359 , 0.6751, 0.9235, 0.9146, 0.9233, 0.9102, 0.8404, 0.7036, 0.6668 and 0.6967 for fruit weight(g.), early and total yield (ton $\mathrm{fed}^{-1}$ ), vitamin $\mathrm{C}$ (mg100g ${ }^{-1}$ fresh wt.) and TSS\% in the first and second seasons, respectively.

\subsubsection{N, $P, K$ and chlorophyll contents in squash leaves}

Data tabulated in Table (7) showed that irrigation treatments had a high significant effect on $\mathrm{N}, \mathrm{P}, \mathrm{K}$ and chlorophyll contents in plant leaves. The highest mean values were recorded under irrigation treatment $\mathrm{I}_{0}$ (Trad. Irrg,) and the values were 3.90 and $3.86 \%$ for $\mathrm{N}, 0.44$ and 0.49 $\%$ for $\mathrm{P}, 3.46$ and $3.38 \%$ for $\mathrm{K}$ and 41.21 and $42.69 \mathrm{mg} \mathrm{dm}^{-2}$ for chlorophyll in the first and second seasons respectively. On the other hand, the least mean values for the abovementioned studied parameters were recorded under irrigation treatment $\mathrm{I}_{3}$ (Ibr., equ.,) and the values were 2.94 and $3.12 \%$ for $\mathrm{N}, 0.32$ and $0.37 \%$ for $\mathrm{P}, 3.15$ and $3.09 \% \mathrm{~K}$ and 29.56 and $28.71 \mathrm{mg}$ $\mathrm{dm}^{-2}$ for chlorophyll in the first and second seasons, respectively. Generally, the mean values for $\mathrm{N}, \mathrm{P}, \mathrm{K}$ and chlorophyll contents can be descended in order $I_{0}>I_{1}>I_{2}>I_{3}$. Increasing the mean values of N,P and $\mathrm{K}$ in the leaves under irrigation $\mathrm{I}_{0}$ might be due to increasing amount of water applied, consequently, increasing solubility of this nutrients and hence their uptake by plants from the soil. For chlorophyll content, it takes the same trend because $\mathrm{I}_{0}$ increased nutrients uptake by plants leading to increasing plant canopy and hence increasing exposed area of the leaves to sunlight which led to increasing chlorophyll content. These results are in agreement with those of Lessani and Mojtahedi (2002)who reported that water deficit can destroy the chlorophyll resulting in a decreased capacity for light harvesting.Moreover,Herbinger et al. (2002) stated that degradation of the absorbing pigments negatively affected the production of reactive oxygen species which are mainly driven byexcess energy absorption in the photosynthetic 

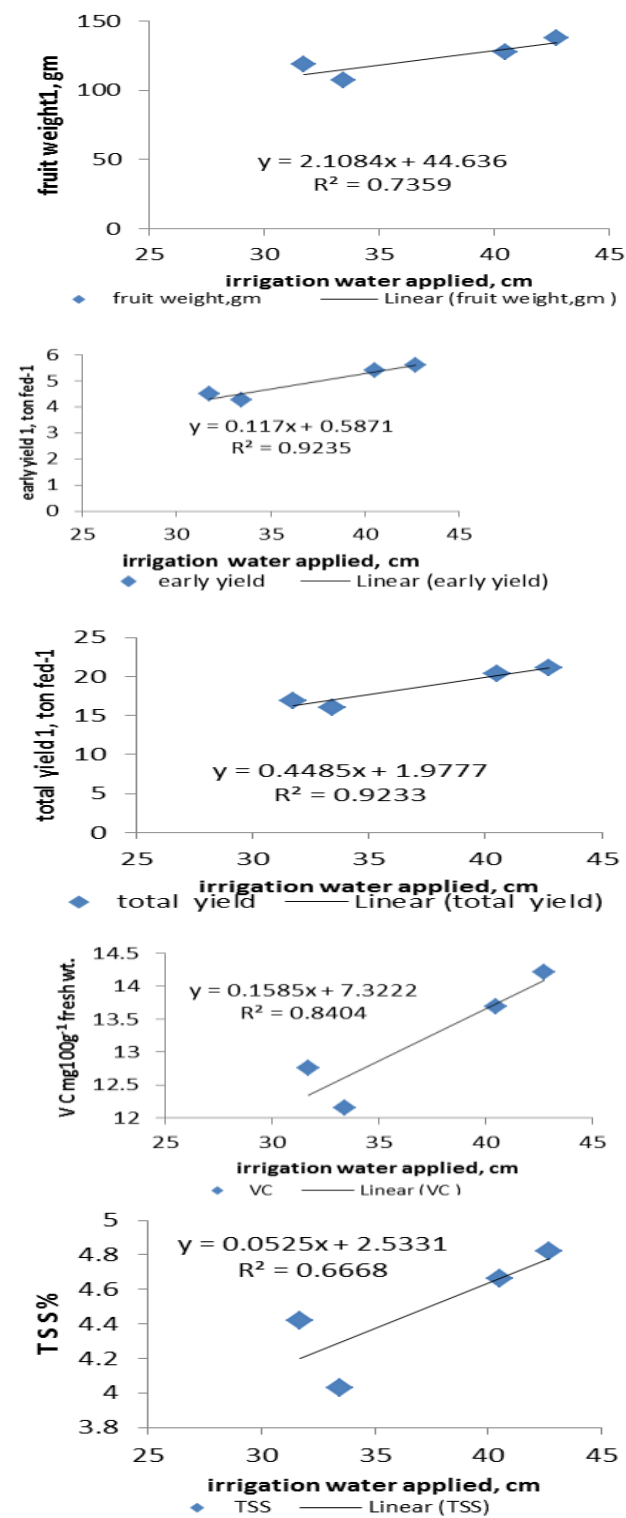
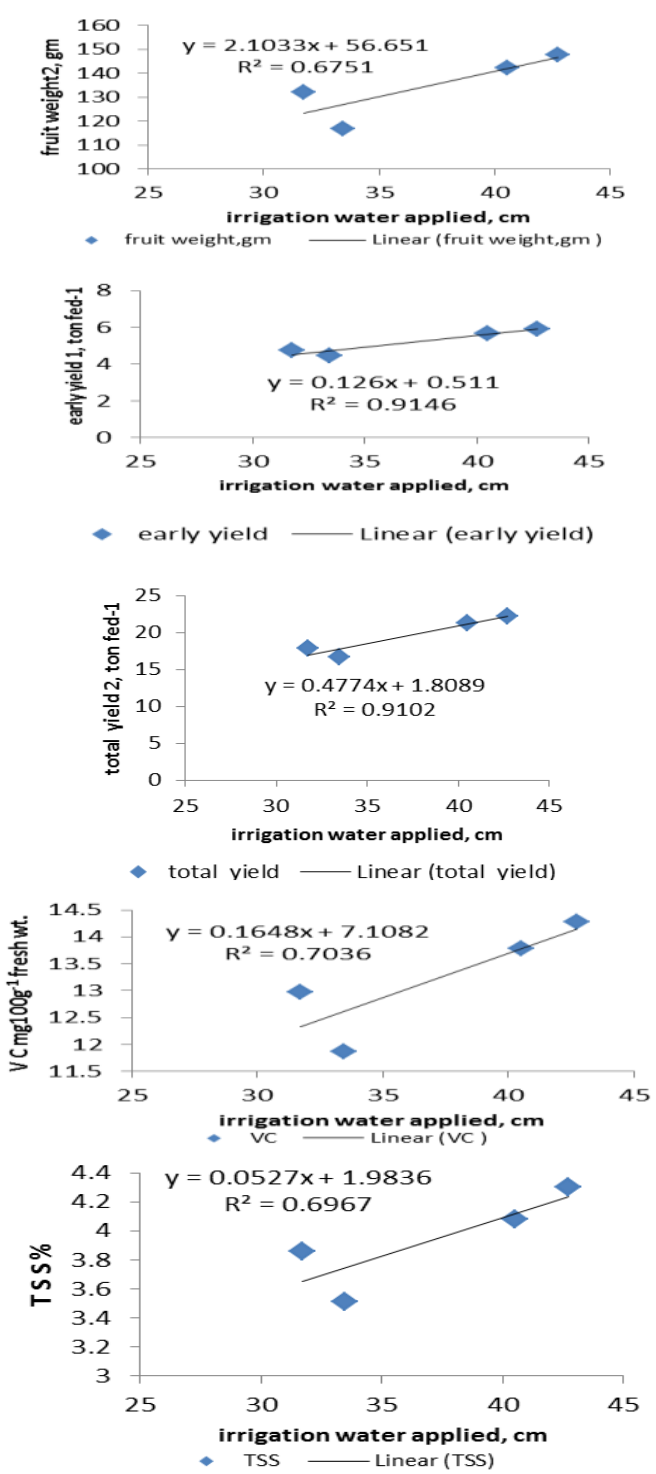

Fig. (3): Correlation between irrigation water applied, $\mathrm{cm}$ overall potassium fertilizer forms on fruit weight (g.), early and total yield (ton $\left.\mathrm{fed}^{-1}\right)$, vitamin $\mathrm{C}\left(\mathrm{mg100g}^{-1}\right.$ fresh wt.) and TSS\%.

apparatus, and Martinez-Ballesta et al. (2010) who reported that one of the environmental stresses affecting mineral content is drought.

Regarding K-fertilization forms, they showed a highly significant effect on N,P, K and chlorophyll contents in the leaves of the plants, the highest mean values for these studied parameters were recorded with $\mathrm{K}_{3}(50 \%$ minera 1 and $50 \%$ feldspar rock) under all irrigation treatments. N P K and chlorophyll exhibited lower values under other K-fertilizer forms and can be arranged in this descending order: $\mathrm{K}_{3}$ > $\mathrm{K}_{4}>\mathrm{K}_{1}>\mathrm{K}_{2}>\mathrm{K}_{5}$ under different irrigation treatments.

In general, irrigation with $\mathrm{I}_{0}$ (control) and $\mathrm{K}_{3}$ $(50 \%$ mineral and $50 \%$ feldspar rock) application technique interaction exhibited higher values of the tested attributes(N,P,K and chlorophyll) in the two seasons of the study.

\section{Recommendations}

Although the traditional (full irrigation method) offers considerable advantage for early and total yield to squash crop under the arid climate, $\mathrm{I}_{1}$ (class A pan) saved about $12 \%$ of IW with alittle negative effect on total yield about $3.5 \%$ and gave the highest WP values for summer squash. Potassium is the nutrient taken up by summer squash in the greatest quantity, it is recommended that it should be fertilized within $(50 \% \mathrm{~K}$-mineral fertilizer and $50 \% \mathrm{~K}$-feldspar). Investigation should focus on this issue and evaluate the efficiency of the irrigation water and K-fertilizer forms for summer squash production. 
Table (7): Effect of irrigation water applied and potassium fertilization forms on N,P,K \% in leaves and chlorophyll, $\mathrm{mgdm}^{-2}$ of squash in the two seasons.

\begin{tabular}{|c|c|c|c|c|c|c|c|c|c|}
\hline \multirow{2}{*}{\multicolumn{2}{|c|}{ Treatments }} & \multicolumn{2}{|c|}{$\begin{array}{l}\mathrm{N} \\
(\%)\end{array}$} & \multicolumn{2}{|c|}{$\begin{array}{c}\mathrm{P} \\
(\%)\end{array}$} & \multicolumn{2}{|c|}{$\begin{array}{c}\mathrm{K} \\
(\%)\end{array}$} & \multicolumn{2}{|c|}{$\begin{array}{l}\text { Chlorophyll, } \\
\left(\mathrm{mgdm}^{-2}\right)\end{array}$} \\
\hline & & 2013 & 2014 & 2013 & 2014 & 2013 & 2014 & 2013 & 2014 \\
\hline \multirow{6}{*}{ 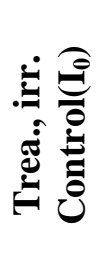 } & $\mathbf{K}_{1}$ & 3.94 & 3.90 & 0.44 & 0.46 & 3.52 & 3.41 & 42.79 & 44.92 \\
\hline & $\mathbf{K}_{2}$ & 3.88 & 3.82 & 0.44 & 0.49 & 3.41 & 3.32 & 39.74 & 40.88 \\
\hline & $\mathbf{K}_{3}$ & 3.98 & 3.92 & 0.45 & 0.54 & 3.63 & 3.58 & 44.53 & 46.24 \\
\hline & $\mathbf{K}_{4}$ & 3.90 & 3.86 & 0.44 & 0.50 & 3.42 & 3.30 & 40.83 & 41.96 \\
\hline & $K_{5}$ & 3.82 & 3.81 & 0.43 & 0.45 & 3.34 & 3.27 & 38.18 & 39.44 \\
\hline & $\begin{array}{c}\text { Mean } \\
\end{array}$ & 3.90 & 3.86 & 0.44 & 0.49 & 3.46 & 3.38 & $\begin{array}{c}41.21 \\
\end{array}$ & 42.69 \\
\hline \multirow{6}{*}{ 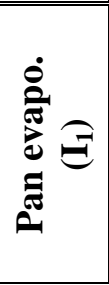 } & $\mathrm{K}_{1}$ & 3.83 & 3.82 & 0.42 & 0.44 & 3.39 & 3.31 & 35.94 & 38.77 \\
\hline & $\mathbf{K}_{2}$ & 3.76 & 3.79 & 0.40 & 0.43 & 3.31 & 3.25 & 32.01 & 35.97 \\
\hline & $\mathbf{K}_{3}$ & 3.86 & 3.84 & 0.43 & 0.45 & 3.41 & 3.36 & 38.71 & 41.09 \\
\hline & $\mathbf{K}_{4}$ & 3.79 & 3.80 & 0.41 & 0.44 & 3.36 & 3.29 & 33.93 & 37.40 \\
\hline & $\mathbf{K}_{5}$ & 3.69 & 3.77 & 0.40 & 0.42 & 3.30 & 3.22 & 31.35 & $\mathbf{3 4 . 8 3}$ \\
\hline & & 3.79 & 3.80 & 0.41 & 0.44 & 3.35 & 3.29 & 34.39 & 37.61 \\
\hline \multirow{6}{*}{ 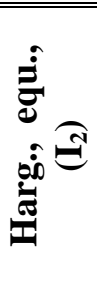 } & $\mathbf{K}_{1}$ & 2.12 & 3.76 & 0.38 & 0.41 & 3.37 & 3.24 & 30.95 & 33.68 \\
\hline & $\mathrm{K}_{2}$ & 3.42 & 3.66 & 0.36 & 0.40 & 3.30 & 3.20 & 29.72 & 30.49 \\
\hline & $K_{3}$ & 3.70 & 3.79 & 0.39 & 0.42 & 3.40 & 3.27 & 32.46 & 34.59 \\
\hline & $\mathbf{K}_{4}$ & 3.52 & 3.71 & 0.37 & 0.41 & 3.34 & 3.22 & 30.42 & 31.94 \\
\hline & $\mathbf{K}_{5}$ & 3.31 & 3.61 & 0.35 & 0.40 & 3.28 & 3.16 & 29.38 & 29.58 \\
\hline & & 3.21 & 3.71 & 0.37 & 0.41 & 3.34 & 3.22 & 30.59 & 32.06 \\
\hline \multirow{6}{*}{ قِ } & $\mathbf{K}_{1}$ & 3.14 & $\begin{array}{l}3.33 \\
\end{array}$ & 0.33 & 0.38 & 3.32 & 3.19 & 30.28 & 29.39 \\
\hline & $\mathbf{K}_{2}$ & 2.72 & 2.92 & 0.32 & 0.36 & 2.99 & 3.07 & 28.67 & 27.75 \\
\hline & $\mathbf{K}_{3}$ & 3.26 & 3.47 & 0.34 & 0.39 & 3.34 & 3.23 & 31.49 & 30.05 \\
\hline & $\mathbf{K}_{4}$ & 2.99 & 3.07 & 0.32 & 0.37 & 3.24 & 3.11 & 28.77 & 28.81 \\
\hline & $\mathbf{K}_{5}$ & 2.59 & 2.79 & 0.30 & 0.34 & 2.87 & 2.83 & 28.59 & 27.57 \\
\hline & & 2.94 & 3.12 & 0.32 & 0.37 & 3.15 & 3.09 & 29.56 & 28.71 \\
\hline \multicolumn{2}{|c|}{ LSD 0.05 } & 0.562 & 0.057 & $\begin{array}{c}0.002 \\
\end{array}$ & 0.029 & $\begin{array}{c}0.0462 \\
\end{array}$ & 0.046 & $\begin{array}{c}0.903 \\
\end{array}$ & 1.104 \\
\hline \multirow{3}{*}{$\underset{\underline{\Phi}}{\overrightarrow{\tilde{E}}}$} & I & $* * *$ & $* * *$ & $* * *$ & $* * *$ & $* * *$ & $* * *$ & $* * *$ & $* * *$ \\
\hline & $\mathbf{K}$ & $*$ & $* * *$ & $* * *$ & $* * *$ & $* * *$ & $* * *$ & $* * *$ & $* * *$ \\
\hline & $\mathbf{I}^{*} \mathbf{K}$ & $* *$ & $* * *$ & $* * *$ & $*$ & $* * *$ & $* * *$ & $* * *$ & $* * *$ \\
\hline
\end{tabular}

\section{REFERANCES}

Abou-el-soud A. A. (2012). Impact of rock materials and bio fertilizations on $\mathrm{p}$ and $\mathrm{k}$ availability of maize (Zea maize) under calcareous soil conditions. Saudia J. biol. Sci., 19: 55-63.

Ali M.H., Hoque M.R., Hassan A.A. and Khair A. (2007). Effect of deficit irrigation on yield water productivity, and economic returns of wheat. Agric. Water Manag., 92 (3): 151-161.

Allen R. G., Pereira L. S., Raes D. and Smith M. (1998). Crop Evapotranspiration: Guidelines for Computing Crop Water Requirements. FAO Irrigation and Drainage Paper 56, Rome, Italy.

Al-Omran A M, Sheta A S, Falatah A M, AlHarbi A. R. (2005).Effect of drip irrigation on squash (Cucurbita pepo) yield and water-use efficiency in sandy calcareous soils amended with clay deposits. Agric. Water Manag., 73: 43-55.

Amer K H. (2011). Effect of irrigation method and quantity on squash yield and quality. Agric. Water Manag., 98, 1197-1206.

AOAC (1980). Association of Official Agricultural Chemists. Official Methods of Analysis. $13^{\text {th }}$ Ed., Washington D.C., U.S.A.

Asmaa R. M. and Magda M. H. (2010). Increasing productivity of potato plants (Solanum tuberosum, 1.) by using potassium fertilizer and humic acid application, 2010, I. J. Academic Res., 2: 83-88. 
Baker A.V. and Pilbeam D.J. (2000). Handbook of plant nutrition. Taylor \&Francis Group,LLC., pp: 662.

Bouman B.A.M., Peng S., Casta neda A. R. and Visperas R. M. (2005). Yield and water use of irrigated tropical aerobic rice systems. Agric. Water Manage.74,87-105.

Brag H. (1972). The influence of potassium on the transpiration rate and stomata opening in Triticum aestivum and Pisum sativum. Physiol, Plant 26: 250-257.

Cabello M.J., Castellanos M.T., Romojaro F., Martınez-Madrid C. and Ribas F. (2009). Yield and quality of melon grown under different irrigation and nitrogen rates. Agric. Water Manag.., 96: 866 - 874.

Dogan E., Kirnak H., Berekatoglu K., Bilgel L. and Surucu A. (2008). Water stress imposed on muskmelon (Cucumis melo L.) with subsurface and surface drip irrigation systems under semiarid climatic conditions. Irrig. Sci., 26 (2): 131-138.

Doornbos J. and Pruit W.O. (1975). Crop water requirements. Irrigation and Drainage Paper, No. 24, FAO Rome.

Ertek A., Ensoy S., Küçükyumuk C. and Gedik I. (2004). Irrigation frequency and amount affect yield components of summer squash (Cucurbita pepo L.). Agric. Water Manage., 67: 63-76.

Fereres E. and Connor D. J. (2004). Sustainable water management in agriculture. In: Cabrera, E., and Cobacho R. (Eds.), Challenges of the New Water Policies for the XXI Century. A. A. Balkema, Lisse, The Netherlands, pp. 157-170.

Fereres E. and Gonzalez- Dugo V. (2009). Improving productivity to face water scarcity in irrigated agriculture. In: Sadras, V.O., Calderini, D.F. (Eds.), Crop Physiology: Applications for Genetic Improvement and Agronomy. Elsevier, Amsterdam, The Netherlands, pp.123-143.

Gomez K. A. and Gomez A. (1984). Statistical procedures for agricultural research. $1^{\text {st }} \mathrm{ed}$. John Wiley \& Sons, New York,U.S.A.

Hansen V.W., Israelsen and Stringharm Q. E. (1979). Irrigation principles and practices, $4^{\text {th }}$ ed., John Willey and Sons, New York, USA.

Hanson B., Orloff S.and Peters D. (2000). Monitoring soil moisture helps refine irriga-tion management. California Agric.54 (3), 38-42.

Hargreaves G.l., Hargreaves G.H. and Riley J.
P. (1985). Irrigation water requirement for Senegal River Basin. $J$ Irrigation at Drainage Engr.,ASCE,111 (3) :265-275.

Hellal F. A., Abd El-Hady M. and Ragab A.A.M. (2009). Influence of organic amendments on nutrient availability and uptake by faba bean plants fertilized by rock phosphate and feldspar. AmerEurasian J. Agric. \& Environ. Sci., 6(3): 271-279.

Herbinger K., Tausz M., Wonisch A., Soja G., Sorger A. and Grill D. (2002). Complex interactive effects of drought and ozone stress on the antioxidant defence systems of two wheat cultivars. Plant Physiol. Biochem., 40: 691-696.

Ibrahim E.A. and Selim E.M. (2007). Effect of irrigation intervals and nitrogen fertilizer rates on summer squash (Cucurbita pepo 1.) growth, yield, nutritional status and water use efficiency. J. Agric. Sci., Mansoura Univ.,Egypt, 32 (12): 1033310345.

Ibrahim M. A. M. (1981). Evaluation of different methods for calculating potential evapotranspiration in North Delta Region. Ph.D. Thesis,Soil\&Water Sci.,Alex. Univ.

Jackson M.L. (1973). Soil chemical analysis. Prentice Hall of India, Private Ltd. New Delhi, India.

James L.G. (1988). Principles of farm irrigation system design. John Willey and Sons Inc., New York, U.S.A. 543.

King E. J.(1951). Micro-analysis in medical biochemistry. $2^{\text {nd }}$ Ed.Churchill,London, UK.

Kirda C., Moutonnet P., Hera C. and Nielsen D.R. (2002). Crop yield response to deficit irrigation. Kluwer Academic Publishers.Dordrecht, The Netherlands.

Klute A. (1986). Water retention: laboratory methods: In: A. Koute (ed). Methods of soil analysis, Part $1,2^{\text {nd }}$ ed. Agron. Monogr. 9, ASA, Madison, W1, USA, pp. 635-660.

Klute A. (1986). Water retention: laboratory methods: In: A . Koute (ed). Methods of soilanalysis, Part $1,2^{\text {nd }}$ ed. Agron. Monoger. 9, ASA, Madison, WI, USA, pp. 635-660.

Labib B. F., Ghabour T. K., Rahim I. S. and Wahba M. M. (2012). Effect of Potassium bearing rock on the growth and quality of potato crop (Solanum tuberosum) J. of Agric.Biotech. and Sustainable Devalop. 4(1): 7-15. 
Lessani H. and Mojtahedi M. (2002). Introduction to Plant Physiology (Translation). $6^{\text {th }}$ Edn., Tehran University press, Iran, ISBN: 964-03-3568-1, pp:726.

Mario H., Bill M., Jason S., John S. (1997). Oregon State University, Western Oregon Sguash Irrigation Guide, Vol. 541. Department of Biores. Engineering, 116 Gilmore Hall, Corvallis, pp. 737-6304 (OR 97331-3906).

Marschner H. (1995). Functions of mineral nitrients:macronutritions, p.299-312.in: $\mathrm{H}$. Marschner, Mineral Nutrition of Higher Plants $2^{\text {nd }}$.ed.Academic press,N.Y., U.S.A.

Martin D.L., Stegman E. C. and Fereres E. (1990). Irrigation scheduling principles. In: Hoffman, G.J., Howell, T.A., Solomon, K.H. (Eds.), Management of farm irrigation systems. ASAE Monograph published by the American Society of Agricultural Engineers, 1st edition, St. Joseph Mich, pp. 155-203.

Martinez-Ballesta M.C., Dominguez-Perles R., Moreno D.A., Muries B., Alcaraz-Lopez C., Bastias E., Garcia Viguera C. and Carvajal M. (2010). Menerals in plant food: Effect of agricultural practices and role on human health. Agronomy for Sustainable Development, 30, 295-309.

Michael A. M. (1978). Irrigation - Theory and practices. Vikas Publishing House, New Delhi, India.

Michael A.M.(2006). Irrigation theory and practice. In: Soil-Plant-Water Relation- ships, Vikas Publishing House Pvt. Ltd, New Delhi, India, pp. 448-584 (Chapter 7, Third ed.).

Moran R. and Porath D. (1982). Chlorophyll determination in intact tissue using $\mathrm{N}, \mathrm{N}$ dimethyl formamide. Plant Physoil., 65: (4): 78-79.

Richard M., Jose A., Mark G. and Keith M. (2002). Summer Squash Production in California. Vegetable Research and Information Center,VegetableReproductio Reproduction Series, California, Publication U.S.A. 7245.

Wallace J.S. (2000). Increasing agricultural water use efficiency to meet future food production. Agric. Ecosyst. Environ., 82: 105-119.

Waller R. A. and Duncan D. B. (1969). Symmetric multiple comparison problem. Amer. Stat. Assoc.,December, 1485-1503.

Wang H., Yang Z., Saito Y., Liu J. P. and Sun $X$. (2006). Interannual and seasonal variation of the Huanghe (Yellow River) water discharge over the past 50 years: Connections to impacts from ENSO events and dams. Global Planet Change, 50: 212-225.

Zotarelli L., Dukes M. D. Scholberg J. M., Hanselman T. , Le Femminella K. and Munõz-Carpena R. (2008). Nitrogen and water use efficiency of zucchini squash for a plastic mulch bed system on a sandy soil. Sci .Hort.., 116, 8-16.

$$
\begin{aligned}
& \text { التاثير المشترك للري وصور التسميد البوتاسي علي إنتاجية محصول الكوسة }
\end{aligned}
$$

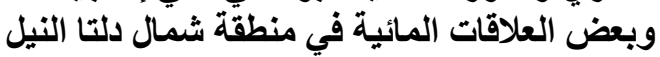

$$
\begin{aligned}
& \text { ضياءالدين خلف فراج - *رضا خالد درويش - *:السيد أبوالفتوح مرسي } \\
& \text { معهد بحوث البساتين ، *معهد بحوث الأر اضي و المياه و البيئة } \\
& \text { مركز البحوث الزراعية ـ الجيزة ـ مصر الأري }
\end{aligned}
$$

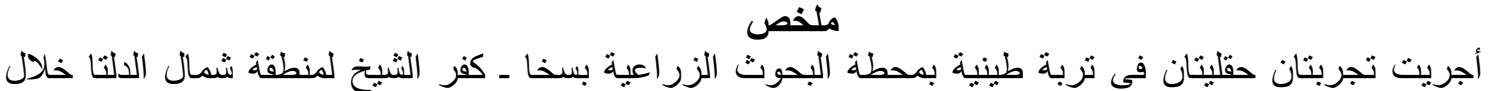

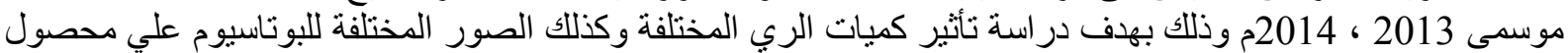

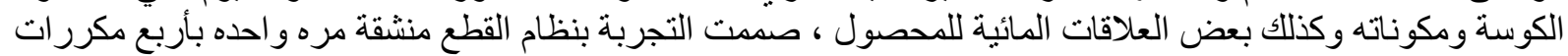

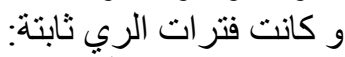

$$
\begin{aligned}
& \text { المعاملات الرئسية : ـ معاملات الرئة الري وهي عبارة عن اربع معاملات }
\end{aligned}
$$

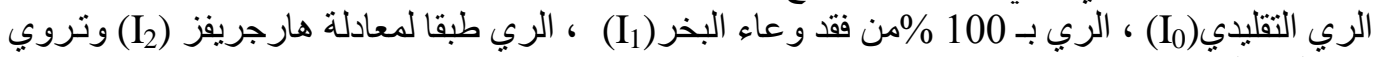

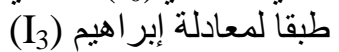

$$
\begin{aligned}
& \text { المعاملات تعت الرئسية:- صور التسميد البوناسي و هي خمس معاملات }
\end{aligned}
$$




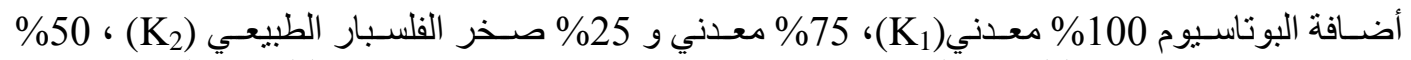

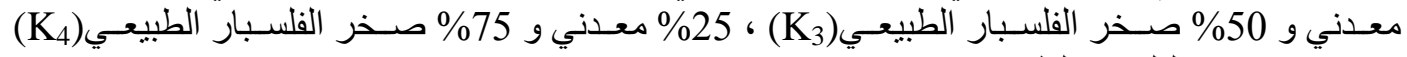

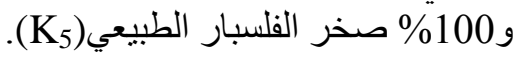

وقد أوضحت النتائج التي تم التوصل اليها ما يلّي:

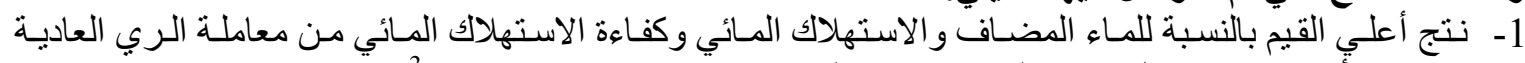

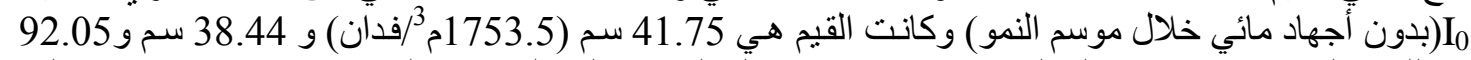

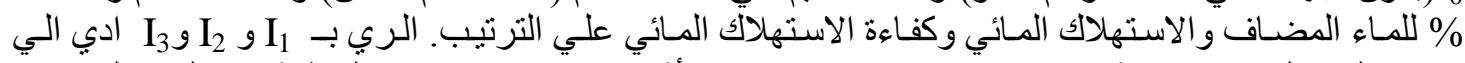

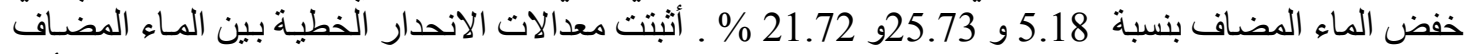

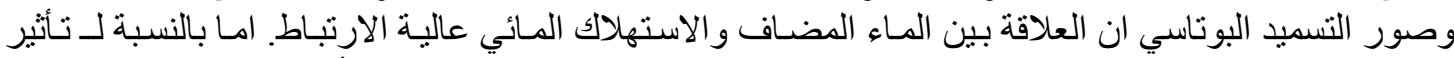

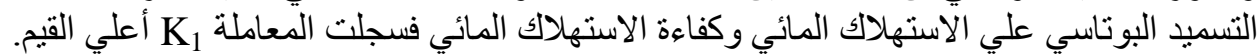

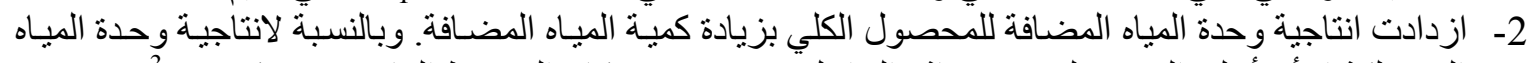

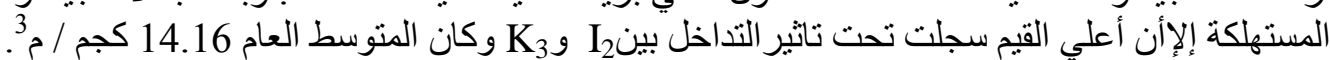

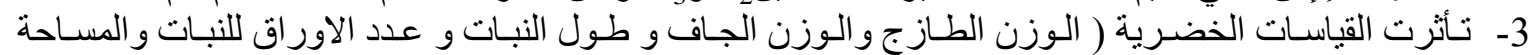

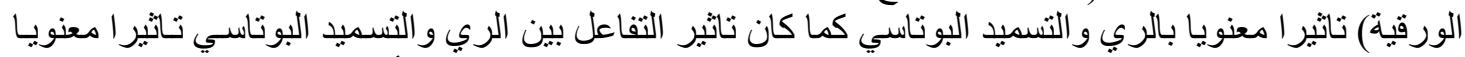

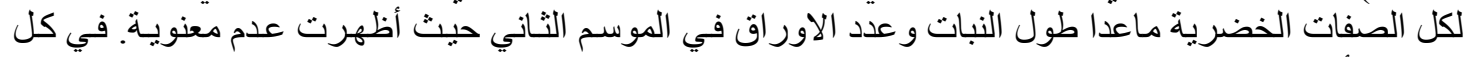

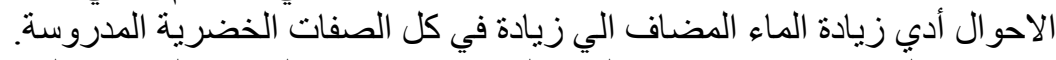

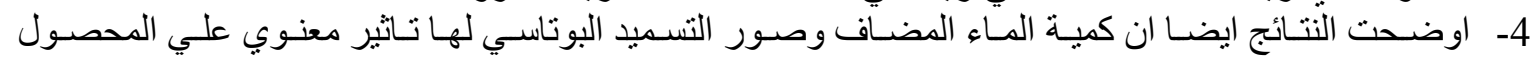

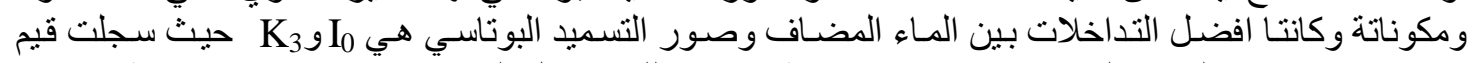

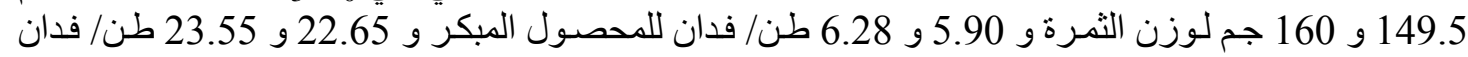

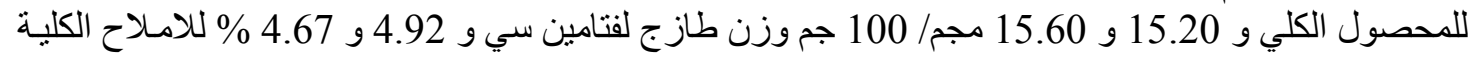
الذائبة للموسم الآول و الثناني علي الترتيب.

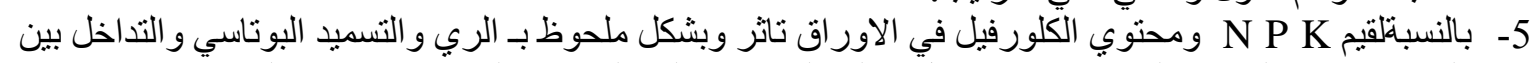

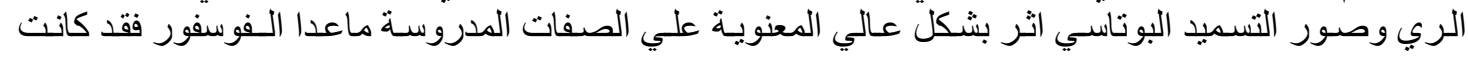
معنوية فقط. وعلية فتوصي الدراسة بـآلآتى:-

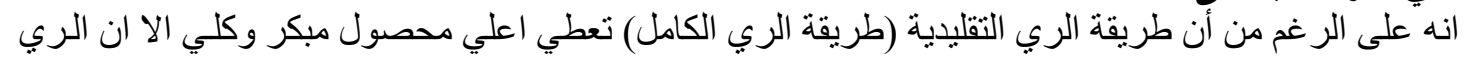

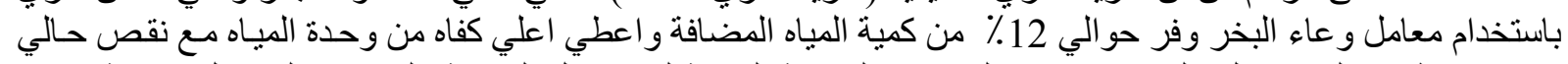

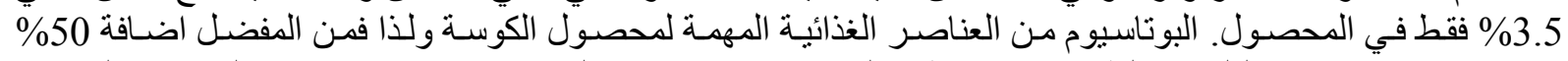

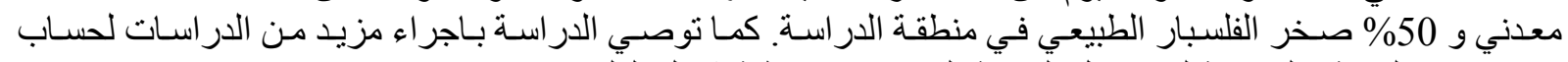

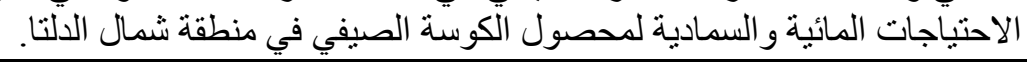

المجلة العلمية لكلية الزراعة - جامعة القاهرة - المجلا (66) العدد الثانى (أبريل 2015): 185-195 ـ 